OPEN ACCESS

Edited by:

Torben Riehl,

Senckenberg Museum, Germany

Reviewed by:

Birger Neuhaus,

Museum of Natural History Berlin

(MfN), Germany

Christoph Plum,

University of Oldenburg, Germany

*Correspondence:

Katarzyna Grzelak

kgrzelak@iopan.gda.pl

Specialty section:

This article was submitted to Deep-Sea Environments and Ecology, a section of the journal

Frontiers in Marine Science

Received: 22 February 2021

Accepted: 07 May 2021

Published: 04 June 2021

Citation:

Grzelak K, Zeppilli D, Shimabukuro M and Sørensen MV (2021) Hadal Mud Dragons: First Insight Into the Diversity of Kinorhyncha From the Atacama Trench. Front. Mar. Sci. 8:670735. doi: 10.3389/fmars.2021.670735

\section{Hadal Mud Dragons: First Insight Into the Diversity of Kinorhyncha From the Atacama Trench}

\author{
Katarzyna Grzelak ${ }^{1,2 *}$, Daniela Zeppilli ${ }^{3}$, Mauricio Shimabukuro ${ }^{3,4}$ and \\ Martin V. Sørensen ${ }^{2}$
}

${ }^{1}$ Marine Ecology Department, Institute of Oceanology, Polish Academy of Sciences, Sopot, Poland, ${ }^{2}$ Natural History Museum of Denmark, University of Copenhagen, Copenhagen, Denmark, ${ }^{3}$ Laboratoire Environnement Profond, Institut Français de Recherche pour l'Exploitation de la Mer (IFREMER), Plouzané, France, ${ }^{4}$ Nordcee and HADAL, Department of Biology, University of Southern Denmark, Odense, Denmark

Deep-sea trenches are one of the last frontiers for deep-sea exploration and represent a large reservoir of undiscovered biodiversity. This applies in particular to organisms belonging to smaller-size classes, such as meiofauna. Among different meiofauna taxa, kinorhynchs represent a large gap in our knowledge about global marine biodiversity in general, but primarily in extreme deep-sea environments. Out of the more than 300 known mud dragon species, only a single species has ever been described from hadal depths (> 6000 m), i.e., Echinoderes ultraabyssalis from the Kuril-Kamchatka Trench. The results presented in this paper are based on material collected during a research expedition in 2018 investigating the Atacama Trench environment. We provide a first overview and comparison of the diversity and abundance of mud dragons in the Atacama Trench, the adjacent abyssal plain and continental slope off Chile. The study revealed six species of Echinoderes. Of these, Echinoderes mamaqucha sp. nov. is described as a new species and morphological data of three undescribed species are given. Because of the low number of available specimens, we provide only a brief description of these three species and comparison with their morphologically closest congeners, but formal descriptions are not given. Moreover, Echinoderes juliae and Echinoderes pterus were also recovered. Echinoderes juliae was described from the abyssal plain off Oregon and along the continental rise off California, at 2702 to $3679 \mathrm{~m}$ depth. Echinoderes pterus is known from the high Arctic, the North Atlantic, and the Mediterranean Sea, and has also been reported to show a wide bathymetric distribution, from 675 to $4403 \mathrm{~m}$. Interestingly, E. mamaqucha sp. nov. dominated at the trench stations and it reached its highest abundance at the deepest station, at $8085 \mathrm{~m}$ water depth. The only other single individual that was found in the Atacama Trench was Echinoderes sp.1. The remaining four species were all found at the abyssal and slope stations. The obtained results seem to confirm previous hypotheses about geographic isolation of deep-sea trenches and relatively low connectivity with other habitats, reflected by limited diversity of sediment dwelling fauna, particularly in the deepest parts of trenches.

Keywords: deep-sea, meiofauna, Echinoderes mamaqucha, new species, taxonomy 


\section{INTRODUCTION}

Kinorhynchs, small meiobenthic organisms with retractable, scalid-covered head and segmented trunk, also known as mud dragons, are exclusively marine invertebrates that occur mostly in muddy or fine-grained sandy sediments, from the shallow waters to the hadal depths (Neuhaus, 2013). A clearer picture of kinorhynch fauna, diversity and community structure at shallower depths is emerging (Sørensen et al., 2012; Yamasaki et al., 2012; Dal Zotto and Todaro, 2016; Landers et al., 2018, 2020; Cepeda et al., 2019a,b; Grzelak and Sørensen, 2019a,b), but knowledge about mud dragons at abyssal (3000-6000 m) and hadal depths $(>6000 \mathrm{~m})$ [for definition of depth zone see Harris et al. (2014) and Jamieson et al. (2010)] is still extremely limited. This is mostly due to the remoteness of the deep-sea ecosystem, technical difficulties in obtaining reliable samples and scarcity of taxonomic expertise.

Deep-sea trenches can reach depths of $11000 \mathrm{~m}$ and their geomorphological features (funnel-like topography, very steep walls, and high hydrostatic pressure) constitute a challenge for logistics and equipment, and thus a serious constrain for biodiversity studies of these habitats (Jamieson et al., 2010). However, information from trenches is essential not only to understand bathymetric patterns in diversity and their regulatory mechanisms in deep-sea environments, but also overall of marine biodiversity and biogeography. These habitats may provide new insights into the factors shaping distribution patterns at the deepsea floor and modify existing ecological paradigms. Trenches are separated from each other by remoteness spaces at abyssal depths, what might support high level of species endemism (Belyaev, 1989). In terms of meiofauna taxa, this statement still needs to be verified.

Hadal trenches remain the least studied and their kinorhynch fauna is almost completely unexplored, as we so far only know about a single identified hadal species, Echinoderes ultraabyssalis Adrianov and Maiorova (2019), described from 9411-9540 $\mathrm{m}$ water depth in the Kuril-Kamchatka Trench (Adrianov and Maiorova, 2019). The only other known records of kinorhynchs from hadal depths are the finding of an unidentified specimen of Echinoderes from $9000 \mathrm{~m}$ in the Kermadec Trench (unpublished finding by D. Leduc, see Zeppilli et al., 2018) and unidentified kinorhynchs from $7200 \mathrm{~m}$ in the Atacama Trench, reported by Danovaro et al. (2002).

The first kinorhynch identified from abyssal depth was Fissuroderes rangi Neuhaus and Blasche (2006) described from the Hikurangi Plateau east of New Zealand at $3202 \mathrm{~m}$ water depth by Neuhaus and Blasche (2006). A few years later Neuhaus and Sørensen (2013) reported Campyloderes cf. vanhoeffeni Zelinka (1913) in the Guinea Basin at $5064 \mathrm{~m}$ and in the southeastern deep-sea region of Canary Island at depths between $5055 \mathrm{~m}$ and $5118 \mathrm{~m}$. Sánchez et al. (2014a,b) described three additional species, i.e., Mixtophyes abyssalis Sánchez et al. (2014a,b), Cristaphyes nubilis (Sánchez et al., 2014a,b), and Krakenella farinelli (Sánchez et al., 2014a,b), from the Guinea Basin, at depths between 5100-5175 m. The remaining and more recent reports of identified abyssal kinorhynchs are restricted to five areas: (1) abyssal plains, 3100-3300 m, around North Atlantic seamounts, from where Yamasaki et al. (2019) describe Echinoderes kaempfae Yamasaki et al., 2019; (2) the East Mediterranean, 675-4403 m, from where Yamasaki et al. (2018a) describe Echinoderes pterus Yamasaki et al., 2018a,b; (3) abyssal plains, 3351-5766, in the vicinity of the Kuril-Kamchatka Trench, from where Adrianov and Maiorova (2015, 2016, 2018a,b) describe Cristaphyes abyssorum (Adrianov and Maiorova, 2015), Condyloderes kurilensis Adrianov and Maiorova (2016), Meristoderes okhotensis Adrianov and Maiorova (2018a), and Parasemnoderes intermedius Adrianov and Maiorova (2018b); (4) the abyssal plains, 3250-3853 m, off the Northwest American continental slope, from where Sørensen et al. (2018) describe E. anniae, E. dubiosus, E. hamiltonorum, E. juliae, E. lupherorum, E. hviidarum, E. yamasakii, and Sørensen et al. $(2018,2019)$ report three additional known kinorhynch species, E. cf. unispinosus Yamasaki et al. (2018a,b), Fissuroderes higginsi Neuhaus and Blasche (2006), and C. kurilensis; (5) the Clarion-Clipperton Fracture Zone, 4319-5012 m, in the tropical East Pacific, from where Sánchez et al. (2019) describe Cephalorhyncha polunga, Echinoderes shenlong, and Meristoderes taro.

The present contribution is the result of studies of kinorhynchs found in samples collected during Cruise SO261, which took place in 2018, in the Atacama Trench region, as part of the multidisciplinary HADES European Research Council (HADES-ERC) study of deep trench systems. Previous studies conducted in the Atacama Trench established the presence of abundant metazoan meiofauna community (Danovaro et al., 2002, 2003) and protozoan Foraminifera (Sabbatini et al., 2002). Despite the fact, that meiobenthos is a key component of benthic fauna inhabiting the Atacama Trench, biodiversity studies have been conducted only for nematodes (Gambi et al., 2003). The main purpose of this study is to provide the first assessment of the species richness and distribution of Kinorhyncha in the Atacama Trench and the adjacent abyssal plain. Here, we contribute with the description of a new species of Echinoderes, the second deepest kinorhynch species described so far. Furthermore, we provide detailed morphological data of three additional undescribed species and report two known species.

\section{MATERIALS AND METHODS}

\section{Study Area}

The study area is located in the Atacama Trench, part of the Peru-Chile Trench system, which is the longest trench of the Pacific Ocean, stretching for almost $6000 \mathrm{~km}$ along the coast of Peru and Chile (Figure 1). The Atacama Trench is narrower than other Pacific trenches (64 km in width), and with a maximum depth of $8065 \mathrm{~m}$ it is the deepest trench of the East Pacific and tenth deepest trench in the world (Jamieson et al., 2010). The Atacama Trench was formed by the subduction of the Nazca and Antarctic plates beneath the continental South American Plate. It is a seismically active area, resulting in occasional gravity-driven sediment slides 


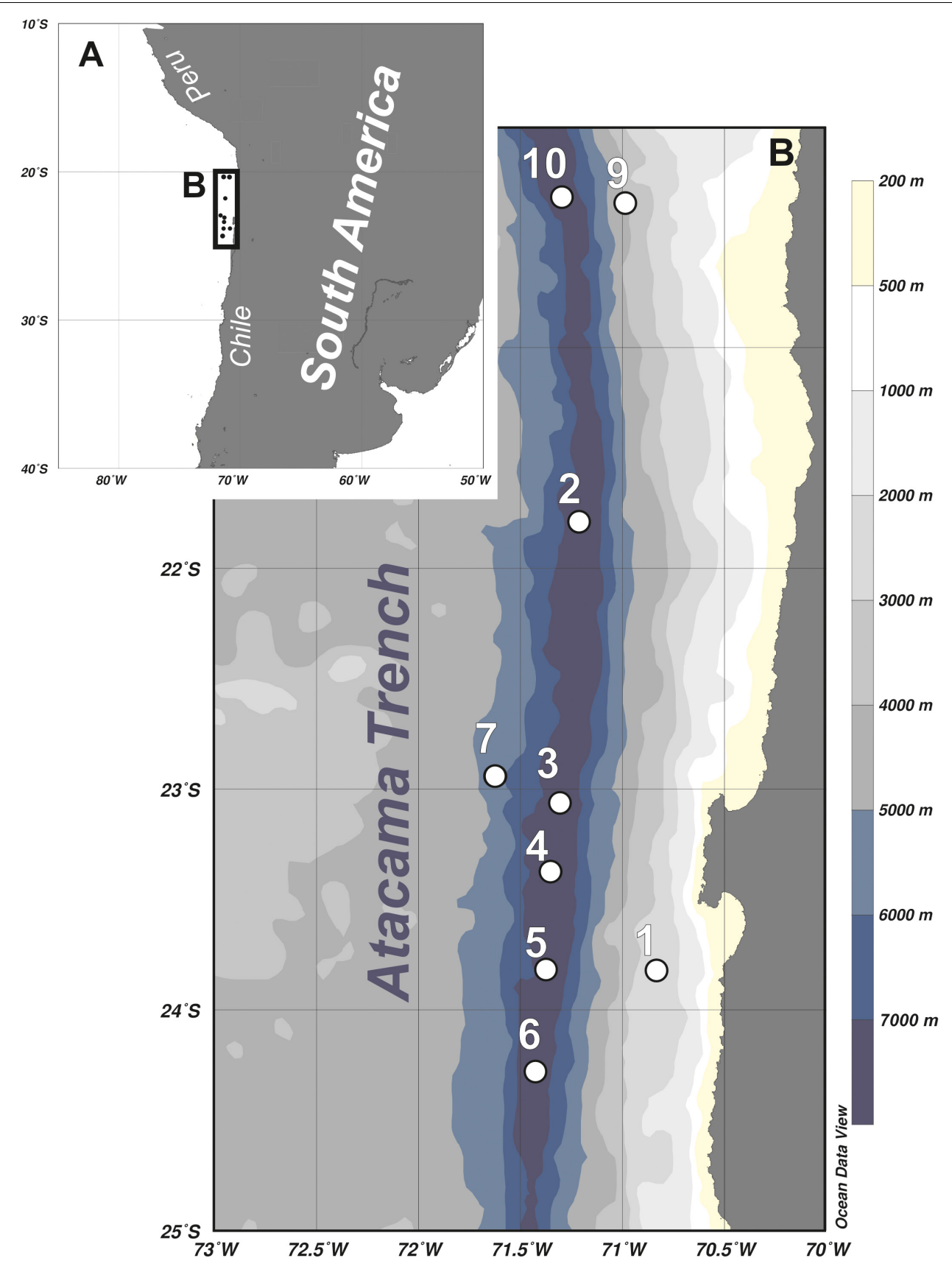

FIGURE 1 | Maps showing location of the Atacama Trench area (A) and detailed overview of the sampling stations (B).

(Lemenkova, 2019). The Atacama Trench is located in an area with significant upwelling events that lead to high primary production (Fossing et al., 1995).

\section{Sample Collection and Preparation}

The sampling was undertaken in March 2018, during the cruise (SO261) with German research vessel RV 'Sonne, within a framework of the multidisciplinary HADES European Research Council (HADES-ERC) study of deep trench systems. A multicorer with tubes of $9 \mathrm{~cm}$ internal diameter was used to retrieve bottom sediment from six stations arranged along the $450-\mathrm{km}$ transect in the Atacama Trench (stations 2 to 6 , and 10) and three stations located at the abyssal plain (7) and continental slope (1 and 9) off the Atacama Trench (Table 1 and Figure 1). From each deployment, three cores were taken from the MUC and subsampled for meiofauna analysis (5 $\mathrm{cm}$ in length and $2.9 \mathrm{~cm}$ in diameter). The samples were fixed with $4 \%$ buffered formaldehyde. In the laboratory samples were washed with freshwater in a $20 \mu \mathrm{m}$ sieve and meiofauna organisms were extracted using centrifugation 
TABLE 1 | Coordinates and basic data of sampling stations and Echinoderes species identities; total no of kino.- total number of processed kinorhynchs (adults and juveniles), species- species identity, together with number of recorded Echinoderes adult specimens, LM-light microscopy, SEM-scanning electron microscopy, NHMD-no - Natural History Museum of Denmark catalog number.

\begin{tabular}{|c|c|c|c|c|c|c|c|c|c|}
\hline Station & Location & Date & Latitude (S) & Longitude (W) & Depth (m) & Total no of kino. & Species & Mounting & NHMD-no \\
\hline \multirow[t]{2}{*}{1} & continental slope & 06.03.2018 & $23^{\circ} 48.72^{\prime}$ & $70^{\circ} 50.04^{\prime}$ & 2560 & 4 & E. juliae (1), & LM & NHMD-872652 \\
\hline & & & & & & & Echinoderes sp. 3 (1) & LM & NHMD-872651 \\
\hline 2 & trench & 23.03.2018 & $21^{\circ} 46.86^{\prime}$ & $71^{\circ} 12.48^{\prime}$ & 7994 & 12 & E. mamaqucha sp. nov. (3) & $\mathrm{LM}+\mathrm{SEM}$ & NHMD-872645-46 \\
\hline 3 & trench & 17.03 .2018 & $23^{\circ} 02.94^{\prime}$ & $71^{\circ} 18.12^{\prime}$ & 7915 & 11 & E. mamaqucha sp. nov. (2) & $\mathrm{LM}+\mathrm{SEM}$ & NHMD-872647 \\
\hline 4 & trench & 14.03 .2018 & $23^{\circ} 21.78^{\prime}$ & $71^{\circ} 20.60^{\prime}$ & 8085 & 26 & E. mamaqucha sp. nov. (10) & $\mathrm{LM}+\mathrm{SEM}$ & NHMD-872636-43 \\
\hline 5 & trench & 11.03 .2018 & $23^{\circ} 49.02^{\prime}$ & $71^{\circ} 22.32^{\prime}$ & 7770 & 14 & E. mamaqucha sp. nov. (2) & LM & NHMD-872648-49 \\
\hline \multirow[t]{2}{*}{6} & trench & 08.03.2018 & $24^{\circ} 15.96^{\prime}$ & $71^{\circ} 25.38^{\prime}$ & 7720 & 12 & E. mamaqucha sp. nov. (2) & $\mathrm{LM}+\mathrm{SEM}$ & NHMD-872635 \\
\hline & & & & & & & Echinoderes sp.1 (1) & LM & NHMD-872653 \\
\hline \multirow[t]{2}{*}{7} & abyssal plain & 20.03.2018 & $22^{\circ} 56.22^{\prime}$ & $71^{\circ} 37.08^{\prime}$ & 5500 & 5 & E. mamaqucha sp. nov. (1) & LM & NHMD-872650 \\
\hline & & & & & & & Echinoderes sp. 2 (1) & LM & NHMD-872654 \\
\hline 9 & continental slope & 28.03.2018 & $20^{\circ} 19.97^{\prime}$ & $70^{\circ} 58.70^{\prime}$ & 4050 & 5 & E. pterus (1) & SEM & \\
\hline 10 & trench & 26.03.2018 & $20^{\circ} 19.14^{\prime}$ & $71^{\circ} 17.46^{\prime}$ & 7770 & 7 & E. mamaqucha sp. nov. (1) & LM & NHMD-872644 \\
\hline
\end{tabular}

with LUDOX solution, following the standard protocol (Vincx, 1996). Kinorhynchs were picked up and stored in a $4 \%$ formaldehyde solution. For preparation of light microscopy (LM) slides, specimens were dehydrated through a graded series of glycerine and mounted in Fluoromount-G. The specimens were examined with an Olympus BX51 microscope with differential interference contrast, and photographed with an Olympus DP27 camera. Measurements were made with Cell^ D software. Line art figures were made with Adobe Illustrator CS6. Specimens for scanning electron microscopy (SEM) were dehydrated through a graded alcohol-acetone series and critical point dried. Dried specimens were mounted on aluminum stubs, sputter coated with a platinum/palladium mix and examined with a JEOL JSM-6335F Field Emission scanning electron microscope.

All specimens were identified to species level, except for the juveniles. Identification of kinorhynchs to species level was based on the relevant taxonomic literature (Herranz et al., 2018; Sørensen et al., 2018; Yamasaki et al., 2018b, 2020; Adrianov and Maiorova, 2019).

\section{RESULTS}

\section{Systematics}

Class Cyclorhagida Zelinka (1896) sensu Sørensen et al. (2015)

Order Echinorhagata Sørensen et al. (2015)

Family Echinoderidae Carus (1885)

Genus Echinoderes Claparède (1863)

Echinoderes mamaqucha sp. nov.

ZooBank.org lsid: zoobank.org:pub:1A9867FF-1C58-4F17A869-F7534B262518.

\section{Material Examined \\ Holotype}

Adult female, collected on March 8, 2018 at station 6 (Figure 1 and Table 1), from $7720 \mathrm{~m}$ depth, in the Atacama Trench $\left(24^{\circ} 15.96^{\prime} \mathrm{S} 71^{\circ} 25.38^{\prime} \mathrm{W}\right)$, mounted in Fluoromount-G, deposited at the Natural History Museum of Denmark, under catalog number NHMD-872635.

\section{Paratypes}

Eleven females and four males collected at stations (station 2, 3, 4, 5, 7, 10) located along the Atacama Trench axis (Figure 1 and Table 1), mounted in Fluoromount-G, deposited at the Natural History Museum of Denmark (NHMD-872636 to NHMD-872650).

\section{Additional Material}

Four females and one male mounted for SEM and stored in the personal collection of MVS.

\section{Etymology}

The species name refers to Mama Qucha, sea- and fish goddess in Inca Mythology, protectress of sailors, and Sea Mother.

\section{Diagnosis}

Echinoderes with middorsal acicular spines on segments 4 to 8 , and in lateroventral positions on segments 6 to 9. Tubes present in subdorsal and ventrolateral positions on segment 2 , lateroventral positions on segment 5 , lateral accessory positions on segment 8 and laterodorsal positions on segment 10; tubes on segment 2 very short and truncate.

\section{Description}

Adults with head, neck and eleven trunk segments (Figures 2A,B, 3A, 4A). Overview of measures and dimensions are given in Table 2. Distribution of cuticular structures, i.e., sensory spots, glandular cell outlets, spines and tubes, is summarized in Table 3.

The head consists of a retractable mouth cone and an introvert (Figure 4B). The external mouth cone armature consists of nine outer oral styles, each composed of two joined units, arranged as one style anterior to each introvert sector, except the middorsal sector 6; each outer oral style with basal fringe consisting of six spinous tips. The introvert was partly retracted in one specimen, and otherwise fully retracted in remaining ones; hence information was only available for the anteriormost scalid 

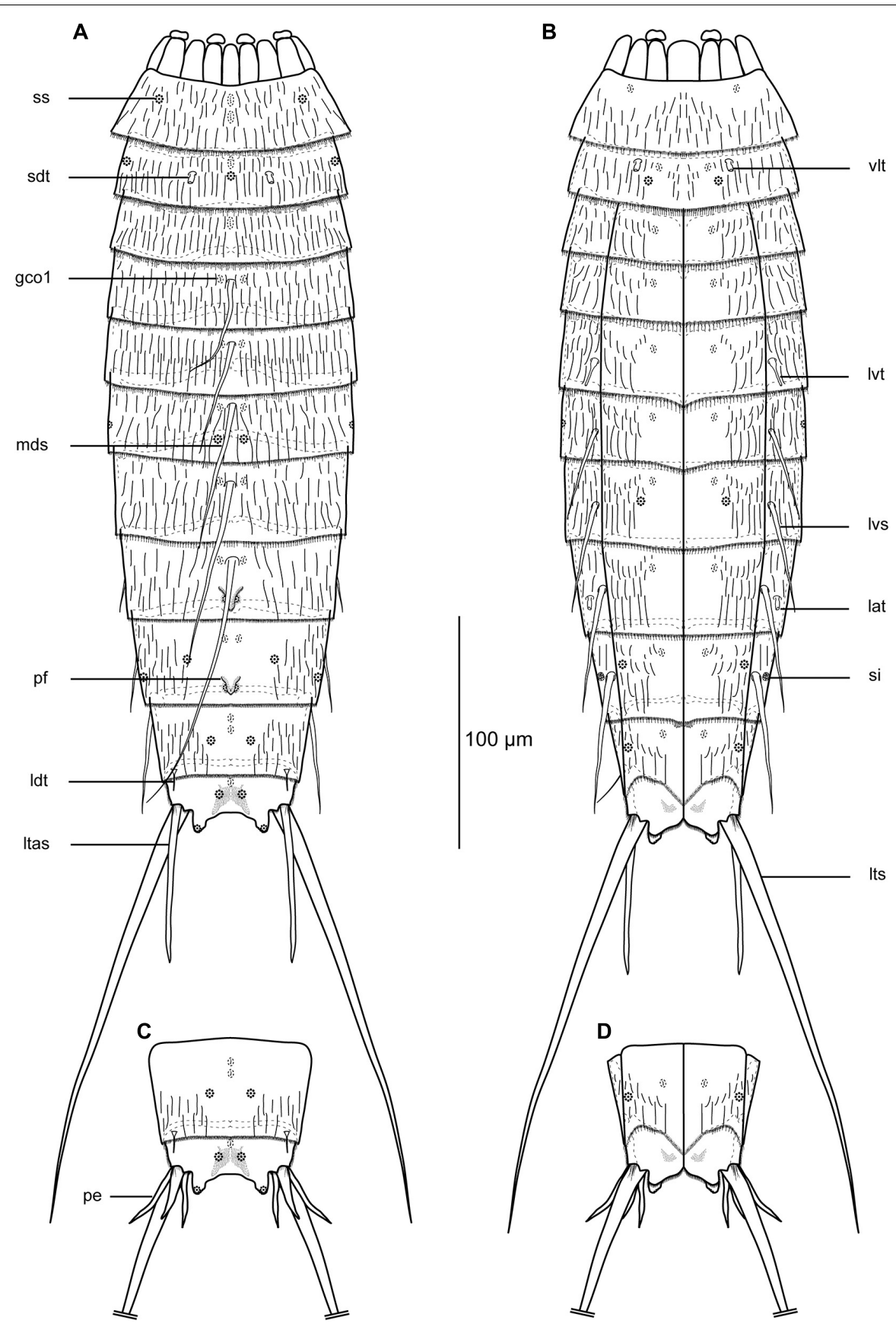

FIGURE 2 | Line art illustrations of Echinoderes mamaqucha sp. nov. (A) female, dorsal view; (B) female ventral view; (C) male, segments 10-11, dorsal view; (D) male, segments 10-11, ventral view. gco1, glandular cell outlet type 1; lat, lateral accessory tube; Idt, laterodorsal tube; Itas, lateral terminal accessory spine; Its, lateral terminal spine; Ivs, lateroventral spine; Ivt, lateroventral tube; mds, middorsal spine; pe, penile spines; pf, papillary flap; sdt, subdorsal tube; si, sieve plate; ss, sensory spot; vlt, ventrolateral tube.

rings. Ten primary spinoscalids present, each consisting of a basal sheath and a distal end piece with a blunt tip. The sheaths have two distinctively differentiated transverse fringes: a most basal fringe with fringe tips attaching to the surface of the scalid, and a slightly more distal fringe where the fringe tips emerge from a transverse furrow; distal to this second fringe, the sheath has a dense hair cover. End pieces are smooth and flexible. Ring
02 has 10 spinoscalids, and Ring 03 has 20 . All spinoscalids in these rings are well-developed, and consist of a basal sheath and a pointed end piece; the basal sheaths of spinoscalids in both rings terminate into fine, fringed margins, whereas those of Ring 03 have in addition a strong, basal median spike (Figure 4B). The number of spinoscalids and their exact morphology could not be determined posterior to Ring 3. 

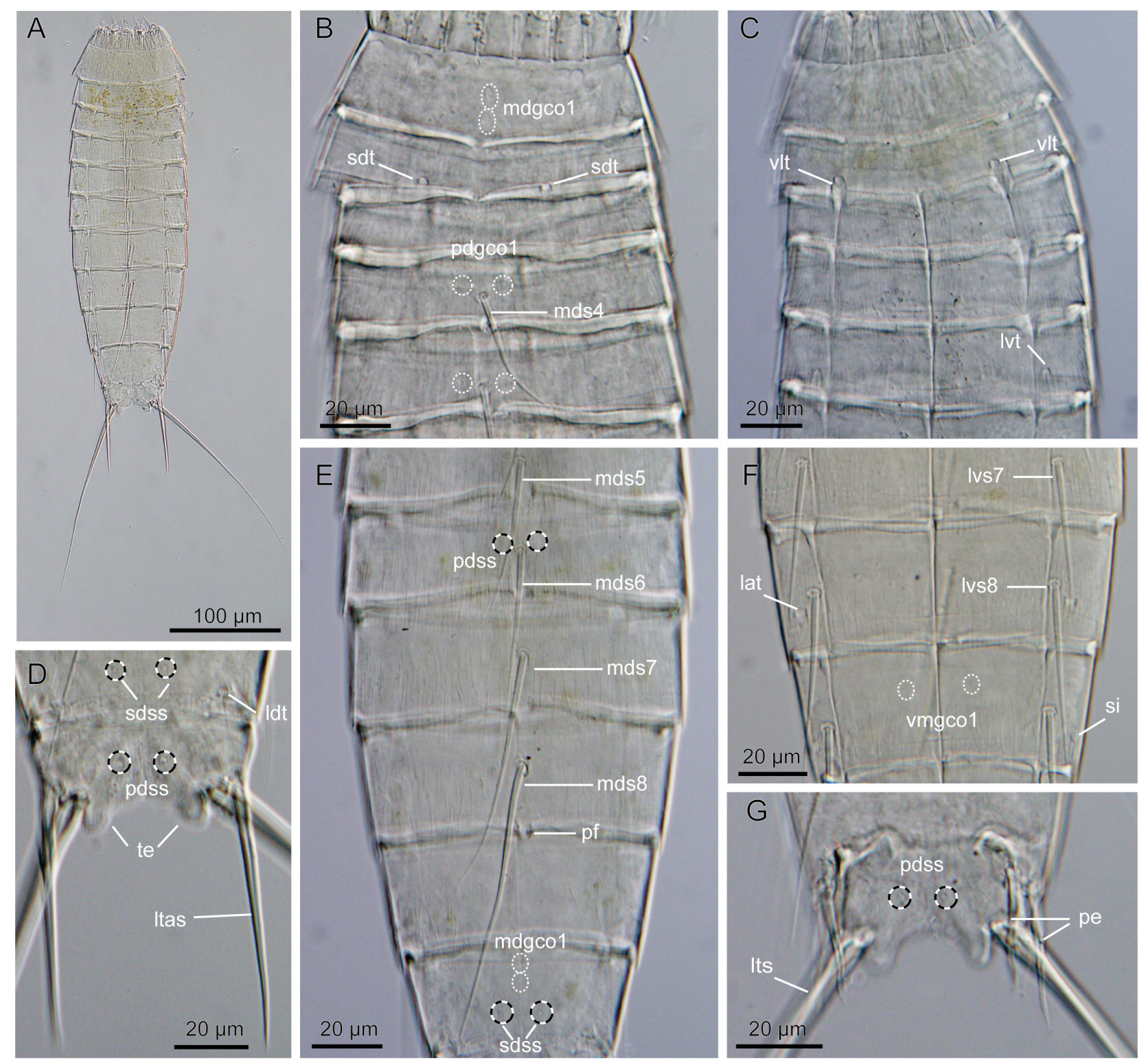

FIGURE 3 | Light micrographs showing overview and details of Echinoderes mamaqucha sp. nov. (A,D-F) Female holotype (NHMD-872635). (B,G) Male paratype (NHMD-872636). (C) Female paratype (NHMD-872641). (A) Ventral overview. (B) Segments 1 to 5, dorsal view. (C) Segments 1 to 5, ventral view. (D) Segments 10 to 11, dorsal view. (E) Segments 5 to 10, dorsal view. (F) Segments 7 to 9, ventral view. (G) Segments 10-11, dorsal view. lat, lateral accessory tube; Idt, laterodorsal tube; Its, lateral terminal spine; Itas, lateral terminal accessory spine; IVs, lateroventral spine, followed by segment number; IVt, lateroventral tube; mdgco1, middorsal glandular cell outlet type 1; mds, middorsal spine, followed by segment number; pdgco1, paradorsal glandular cell outlet type 1; pdss, paradorsal sensory spot; pe, penile spine; pf, papillary flap; sdss, subdorsal sensory spot; sdt, subdorsal tube; si, sieve plate; te, tergal extension; vit, ventrolateral tube; vmgco1, ventromedial glandular cell outlet type 1.

Neck with 16 placids. Midventral placid broadest, $12 \mu \mathrm{m}$ in width and $18 \mu \mathrm{m}$ in length. Remaining placids narrower, $9 \mu \mathrm{m}$ in width and $17 \mu \mathrm{m}$ in length, similar in size. Four dorsal and two ventral trichoscalid plates are present, each carrying a thick and bushy trichoscalid.

Segment 1 consists of a complete cuticular ring (Figures 2A,B, 3B,C, 4A,C,D). One pair of sensory spots is located in laterodorsal positions, anterior on the segment, but not at anterior margin. Sensory spots on this and following segments small and rounded, with numerous micropapillae surrounding a central pore (Figures 4C,D,F-H). Two longitudinally arranged glandular cell outlets type 1 present in middorsal position, and one additional pair present in lateroventral positions (Figures 4C,D). Cuticular hairs relatively well-spaced, distributed evenly around the segment, except in hairless ventromedial areas on anterior segment half (Figures 4C,D). Posterior segment margin almost straight, forming a pectinate fringe; pectinate fringe tips 

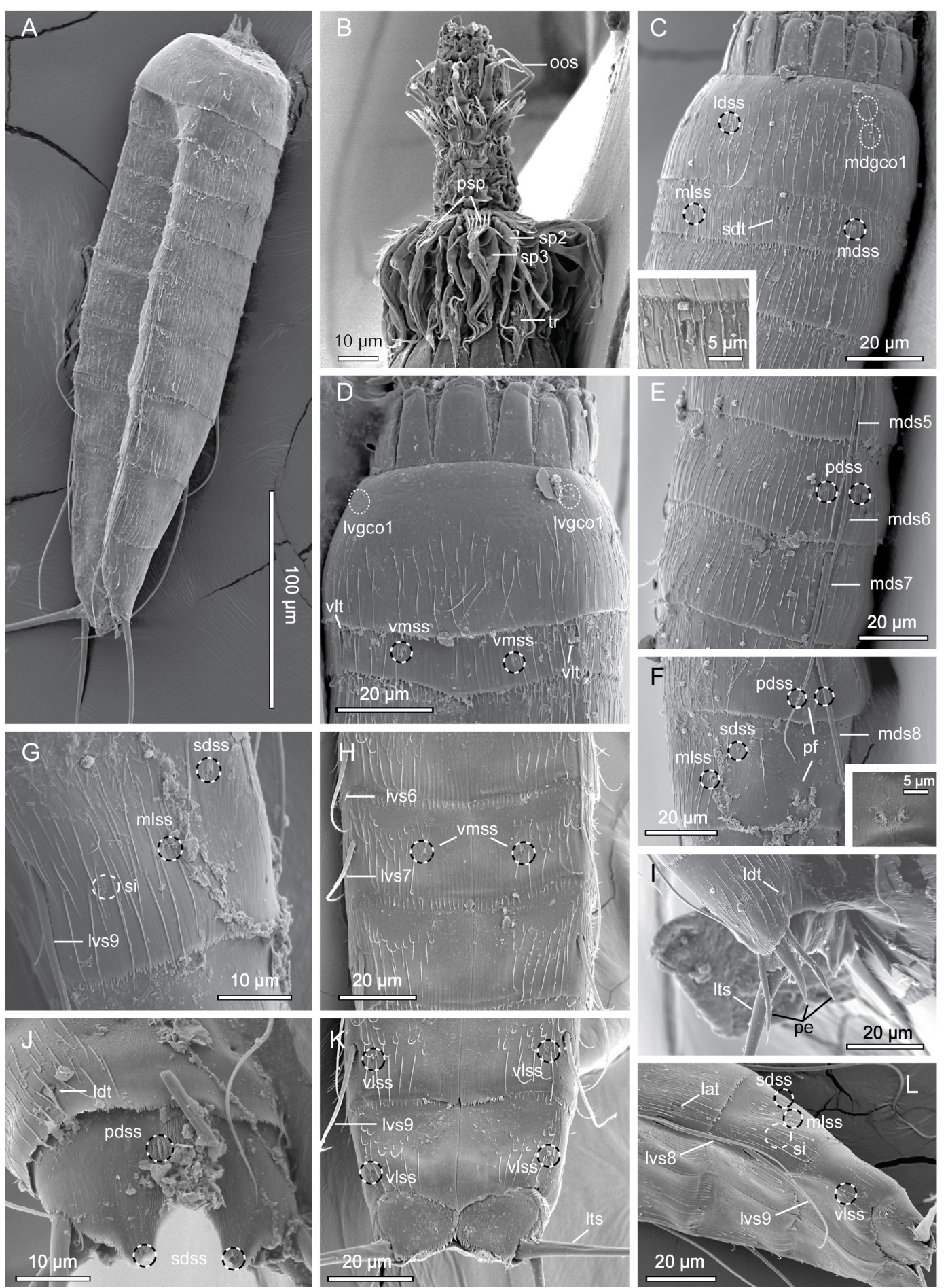

FIGURE 4 | Scanning electron micrographs showing overviews and details of Echinoderes mamaqucha sp. nov. (A) Lateroventral overview. (B) Mouth cone and introvert sectors 8 to 7. (C) Segments 1 to 3, dorsolateral view, with close-up showing subdorsal tube on segment 2. (D) Segments 1 to 2, ventral view.

(E) Segments 5 to 7, dorsolateral view. (F) Segments 8 to 9, dorsolateral view, with close-up showing papillary flap on segment 9. (G) Segment 9, lateral view. (H) Segments 6 to 8, ventral view. (I) Segments 10 to 11 of male, lateral view. (J) Segments 10 to 11 of female, dorsal view. (K) Segments 9 to 11 of female, ventral view. (L) Segments 8 to 11, lateroventral view. lat, lateral accessory tube; Idss, laterodorsal sensory spot; ldt, laterodorsal tube; Its, lateral terminal spine; Ivgco1, lateroventral glandular cell outlet type 1; Ivs, lateroventral spine, followed by segment number; mdgco 1, middorsal glandular cell outlet type 1; mds, middorsal spine, followed by segment number; $m d s s$, middorsal sensory spot; $\mathrm{m} / \mathrm{ss}$, midlateral sensory spot; oos, outer oral style; pdss, paradorsal sensory spot; pe, penile spine; $p f$, papillary flap; $p s p$, primary spinoscalid; sdss, subdorsal sensory spot; $s d t$, subdorsal tube; si, sieve plate; $s p$, spinoscalid followed by introvert ring number; $t r$, trichoscalid; vlss, ventrolateral sensory spot; vlt, ventrolateral tube; vmss, ventromedial sensory spot. 
TABLE 2 | Measurements from light microscopy of Echinoderes mamaqucha sp. nov. (in $\mu \mathrm{m}$ ) from the Atacama Trench, including number of measured specimens (n) and standard deviation (SD).

\begin{tabular}{|c|c|c|c|c|}
\hline Character & $n$ & Range & Mean & SD \\
\hline $\mathrm{TL}$ & 16 & $252-325$ & 296 & 20.8 \\
\hline MSW-6 & 16 & $63-69$ & 67 & 1.7 \\
\hline MSW-6/TL & 16 & $20.8-26.7 \%$ & $22.9 \%$ & $1.8 \%$ \\
\hline SW-10 & 16 & $53-56$ & 54 & 0.9 \\
\hline SW-10/TL & 16 & $16.8-21.6 \%$ & $18.4 \%$ & $1.4 \%$ \\
\hline S1 & 16 & 28-35 & 31 & 1.8 \\
\hline $\mathrm{S} 2$ & 16 & $24-30$ & 26 & 1.6 \\
\hline S3 & 16 & $24-31$ & 27 & 1.7 \\
\hline S4 & 16 & 28-35 & 30 & 1.9 \\
\hline S5 & 16 & $29-36$ & 32 & 1.8 \\
\hline S6 & 16 & $34-40$ & 36 & 1.9 \\
\hline S7 & 16 & $34-42$ & 38 & 1.8 \\
\hline S8 & 16 & $39-45$ & 42 & 1.6 \\
\hline S9 & 16 & $39-44$ & 41 & 1.7 \\
\hline $\mathrm{S} 10$ & 16 & $33-43$ & 36 & 3.2 \\
\hline S11 & 16 & 25-32 & 28 & 2.0 \\
\hline MD4 (ac) & 16 & $35-43$ & 40 & 2.4 \\
\hline MD5 (ac) & 15 & $43-53$ & 47 & 3.1 \\
\hline MD6 (ac) & 15 & $47-57$ & 52 & 3.5 \\
\hline MD7 (ac) & 16 & $63-80$ & 72 & 4.6 \\
\hline MD8 (ac) & 16 & $96-120$ & 109 & 7.5 \\
\hline LV6 (ac) & 16 & $34-42$ & 38 & 2.4 \\
\hline LV7 (ac) & 16 & $40-49$ & 45 & 2.9 \\
\hline LV8 (ac) & 16 & $49-57$ & 54 & 2.1 \\
\hline LV9 (ac) & 16 & $58-69$ & 64 & 3.3 \\
\hline LTS & 16 & 170-206 & 187 & 9.7 \\
\hline LTS/TL & 16 & $54.4-75.8 \%$ & $63.5 \%$ & $6.7 \%$ \\
\hline LTAS & 12 & $58-72$ & 68 & 3.9 \\
\hline
\end{tabular}

(ac), acicular spine; LTAS, lateral terminal accessory spine; LTS, lateral terminal spine; LV, lateroventral; MD, middorsal; MSW-6, maximum sternal width, measured on segment 6 in this species; S, segment lengths; SW-10, standard width, always measured on segment 10; TL, trunk length.

thin, weakly developed, well-spaced with even shorter and finer tips in between.

Segment 2 consists of a complete cuticular ring, with minute $(<5 \mu \mathrm{m})$ tubes located in subdorsal and ventrolateral positions (Figures 3B,C, 4C,D); tubes are not differentiated into thick proximal part and thinner distal tubular part with lateral wings, but are merely short tubular, truncate tips. Sensory spots present in middorsal, midlateral and ventromedial positions. Glandular cell outlets type 1 present in middorsal and ventromedial positions. Pachycyclus of anterior segment margin interrupted in middorsal position. Secondary pectinate fringe present near anterior segment margin of this and following segments, but usually covered by the preceding segment. Cuticular bracteate hairs lightly scattered on ventral side and more densely in dorsal and lateral areas. Pectinate fringe tips slightly longer than on preceding segment, but still very flexible; margin between tips very finely serrated.

Segment 3, and remaining segments, consists of one tergal and two sternal plates; pachycycli of anterior segment margins with interruption in middorsal positions and around tergosternal and midsternal junctions. Segment with glandular cell outlets type 1, located in middorsal and ventromedial positions. On this and following seven segments, cuticular hairs arranged in two to three rows across the tergal plate, except for hairless midlateral areas, and on the lateral halves of the sternal plates; paraventral and ventromedial areas devoid of hairs. Pectinate fringe as on preceding segment.

Segment 4 with flexible acicular spine in middorsal position and pairs of glandular cell outlets type 1 located in paradorsal and ventromedial positions (Figures 2A,B, 3B). Cuticular hairs, and pectinate fringe of posterior margin as on preceding segment.

Segment 5 with acicular spine in middorsal position and relatively short $(10 \mu \mathrm{m})$ tubes in lateroventral positions (Figures 2A,B, 3C,E); tubes are longer and more slender than those on segment 2, but without the common differentiation into thick bases and end piece with lateral wings. Pectinate fringe tips of posterior margin slightly longer; glandular cell outlets type 1, and cuticular hairs otherwise as on preceding segments.

Segment 6 with acicular spines in middorsal and lateroventral positions (Figures 2A,B, 3E, 4E,H). Sensory spots present in paradorsal and midlateral positions. Glandular cell outlets type 1, and pectinate fringe of posterior margin as on preceding segment.

Segment 7 with acicular spines in middorsal and lateroventral positions (Figures 2A,B, 3E,F, 4E,H). One pair of sensory spots located ventromedially. One specimen (out of five examined under SEM) lacked this character and one showed only one sensory spot on the right sternal plate; for some specimens examined under LM presence/absence of ventromedial sensory spots could not be confirmed. Other structures as on preceding segment.

Segment 8 with acicular spines in middorsal and lateroventral positions (Figures 2A,B, 3E,F, 4L). Middorsal spine long, reaching posterior part of segment 11 , but never exceeding its margin (Figure 3G). Short tubes $(<10 \mu \mathrm{m})$ present in lateral accessory positions (Figures $3 \mathrm{~F}, \mathbf{4 L}$ ); tubes resemble those on segment 2. Sensory spots located in paradorsal positions only, hardly visible due to the presence of a papillary flap - a $\mathrm{V}$-shaped structure present middorsally at the posterior part of the segment (Figures 2A, 3E, 4F). Glandular cell outlets type 1 present in paradorsal and ventromedial positions. Cuticular hairs on sternal plates as on preceding segment; hairs on tergal plate scarcer with hairless middorsal and paradorsal patches (Figure 4H). Pectinate fringe of posterior margin with shorter tips, on dorsal side much less developed in comparison to preceding segment.

Segment 9 with a pair of lateroventral spines. Rounded and very small sieve plates present in sublateral positions (Figures 2B, 3F, 4G). Sensory spots present in paradorsal, subdorsal, midlateral and ventrolateral positions (Figures $2 \mathbf{A}, \mathbf{B}$, 4F,G,K,L). Paradorsal pair difficult to detect due to the presence of a papillary middorsal flap, which however is smaller than on preceding segment (Figure 4F). Cuticular hair covering less dense than on preceding segment; central part of the tergal plate devoid of hairs. Pectinate fringe tips slightly shorter on lateral 
TABLE 3 | Summary of nature and location of sensory spots, glandular cell outlets, tubes and spines arranged by series in Echinoderes mamaqucha sp. nov.

\begin{tabular}{|c|c|c|c|c|c|c|c|c|c|c|}
\hline $\begin{array}{l}\text { Position } \\
\text { Segment }\end{array}$ & MD & PD & SD & LD & ML & SL & LA & $\mathbf{L V}$ & VL & VM \\
\hline 1 & gco1,gco1 & & & ss & & & & gco1 & & \\
\hline 2 & gco1,ss & & tu & & ss & & & & tu & gco1,ss \\
\hline 3 & gco1 & & & & & & & & & gco1 \\
\hline 4 & $\mathrm{ac}$ & gco1 & & & & & & & & gco1 \\
\hline 5 & ac & gco1 & & & & & & tu & & gco1 \\
\hline 6 & $\mathrm{ac}$ & gco1,ss & & & SS & & & $\mathrm{ac}$ & & gco1 \\
\hline 7 & $\mathrm{ac}$ & gco1 & & & & & & $\mathrm{ac}$ & & gco1,ss* \\
\hline 8 & $\mathrm{ac}$ & gco1,ss & & & & & tu & $\mathrm{ac}$ & & gco1 \\
\hline 9 & & gco1,ss & ss & & ss & si & & $\mathrm{ac}$ & ss & gco1 \\
\hline 10 & gco1,gco1 & & ss & tu & & & & & ss & gco1 \\
\hline 11 & gco1 & ss & ss & & pe x3 $\left(0^{\pi}\right)$ & & Itas(o) & Its & & \\
\hline
\end{tabular}

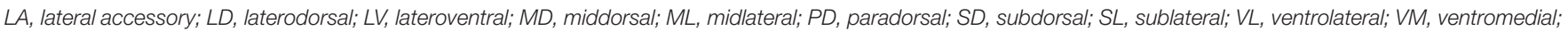

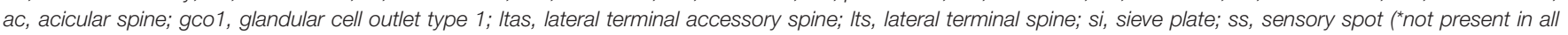
specimens); tu, tube; (q), female condition of sexually dimorphic characters; (o'), male condition of sexually dimorphic characters.

sides, otherwise as on preceding segment. Glandular cell outlets type 1 as on preceding segments.

Segment 10 with minute, very slender laterodorsal tubes near posterior segment margin (Figures 2A,C, 3D, 4I,J); appearance of the tubes similar in both sexes. Sensory spots present in subdorsal and ventrolateral positions. Subdorsal pair located in the middle of the segment, but in a few cases, one sensory spot is shifted posteriorly to a position very close to posterior segment margin. Glandular cell outlets type 1 present as two middorsal ones and one pair in ventromedial position. Cuticular hairs scarcer than on preceding segment. Anterior part of the tergal plate devoid of hairs; hairs on the sternal plates short and present mostly on the lateral halves and near posterior segment margin. Margins of the sternal plates extend midventrally (Figure $4 \mathbf{K}$ ). Pectinate fringe with very short tips.

Segment 11 with a pair of long lateral terminal spines (Figures 2A,B, 3A). Females with strong, stout lateral terminal accessory spines (Figures 2A,B, 3A,D). Males with three pairs of penile spines; median penile spine stouter than dorsal and ventral ones, but all three pairs generally stout and rigid, gradually tapering in distal 1/4 (Figures 2C,D, 3G, 4I). Sensory spots present in paradorsal and subdorsal positions. The latter ones located at the posterior margin of the tergal extensions (Figure 4J). One middorsal glandular cell outlet type 1 present. Tergal extensions short and rounded (Figures 2, 3D,G). The posterior margin of the sternal plates also rounded, not exceeding beyond, but nearly as long as tergal extensions. Pectinate fringe of posterior margin with short tips, except in lateral positions where longer and more flexible fringe tips are present. The segment completely devoid of cuticular hairs, but has a relatively dense covering of hair-like extensions in the mid- and paradorsal positions, as well as small patches present in paraventral and ventromedial areas.

\section{Differential Diagnosis}

The spine and tube distribution in the middorsal and lateroventral series of E. mamaqucha sp. nov., with middorsal spines on segments 4 to 8 , and tubes/spines in lateroventral positions of segments 5 to 9 is the most common pattern observed among species of Echinoderes and is shared by 44 congeners (Yamasaki et al., 2020). However, when we combine these characters with the presence of subdorsal and ventrolateral tubes on segment 2 we shorten the list to only 3 species, i.e., E. adrianovi Herranz et al. (2014), E. levanderi Karling (1954), E. kanni Thormar and Sørensen (2010) (Karling, 1954; Thormar and Sørensen, 2010; Herranz et al., 2014; Sørensen, 2018). Despite the coincidence of spine/tube formula E. mamaqucha sp. nov. can still be easily distinguished from the abovementioned species based on other traits, e.g., very short tubules, dimensions of acicular spines, shape of tergal extension, and general appearance of primary pectinate fringe. Echinoderes levanderi cannot in any way be confused with E. mamaqucha sp. nov. since the morphometrics of both species differ significantly. Echinoderes levanderi is conspicuously larger, has markedly longer lateral terminal spines, and consequently, shows a larger proportion of lateral terminal spine to trunk length $(90.5 \%)$ than E. mamaqucha sp. nov. (63.5\%). Most importantly, however, E. levanderi possesses sublateral tubes on segments 5 and 8 , very characteristic large sieve plates, pointed tergal extension and extremely well-developed pectinate fringes with very long tips throughout the body (Sørensen, 2018). Echinoderes mamaqucha sp. nov. is more similar to E. kanni and E. adrianovi, and shares the presence of lateral accessory tubes on segment 8, dorsal tubes on segment 10 and the absence of glandular cell outlet types 2 (Thormar and Sørensen, 2010; Herranz et al., 2014). Nevertheless, both species can be distinguished from E. mamaqucha sp. nov. by their markedly longer (up to 2-4 times) tubes, much shorter and thinner lateral accessory terminal spines, and pointed tergal extensions (Thormar and Sørensen, 2010; Herranz et al., 2014; Yamasaki et al., 2019). Both species also have very prominent cuticular perforation sites which are missing in E. mamaqucha sp. nov.

Interestingly, E. mamaqucha sp. nov. shows a much closer general resemblance with E. bathyalis Yamasaki et al. (2018a,b) and E. dubiosus Sørensen et al. (2018). Both are deep-water 
species, described from East Atlantic (> $2500 \mathrm{~m}$ water depth) and North-Eastern Pacific (> $3500 \mathrm{~m}$ water depth), respectively (Sørensen et al., 2018; Yamasaki et al., 2018b). Echinoderes mamaqucha sp. nov. and these two species share identical spine patterns and are characterized by having a long middorsal spine on segment 8 and long lateroventral spines on segment 9. The spines easily reach and even extend beyond the posterior margin of segment 10. However, in E. mamaqucha sp. nov. none of them extends beyond the posterior margin of segment 11, whereas in the two latter species the middorsal spine on segment 8 and lateroventral spines on segment 9 always extent beyond the terminal segment (Sørensen et al., 2018; Yamasaki et al., 2018a,b). Echinoderes mamaqucha sp. nov. also resemble the two species in terms of trunk shape and length, and in possessing short tergal extension. Nevertheless, the posterior edge of the tergal plate is more pointed in E. bathyalis and E. dubiosus. In addition, E. mamaqucha sp. nov. has uncommon middorsal structures on segments 8 and 9 that resemble those reported for the first time from E. dubiosus and described as papillary flap (Sørensen et al., 2018). This trait is present on segment 9 only in E. dubiosus, but its similarity with the structures found on segments 8 and 9 in E. mamaqucha sp. nov. is striking. Sørensen et al. (2018) described the structure as "papillary flap or tuft of papillae, flanked by a pair of paradorsal sensory spots," which is exactly what can be observed for E. mamaqucha sp. nov. Furthermore, similar to E. dubiosus, E. mamaqucha has laterodorsal tubes on segment 10 and lateral tubes on segment 8. In the latter species, tubes are located in lateral accessory position, whereas they are sublateral in E. dubiosus. The most striking difference between E. mamaqucha sp. nov and two other species is, however, the tube arrangement on segment 2 . While E. mamaqucha sp. nov. is characterized by the presence of subdorsal and ventrolateral tubes on this segment, both E. dubiosus and E. bathyalis lack this character, and have instead one pair of glandular cell outlet type 2 in midlateral position. Even though the tubes in the new species are extremely short and sometimes difficult to visualize in LM, and that the attachments of tubes might sometimes resemble glandular cell outlets type 2 , the structures still appear in different positions. Therefore, presence of tubes on segment 2 makes E. mamaqucha sp. nov. easily distinguishable from its two other deep-sea, and potentially closely related, congeners.

\section{Other Species of Echinoderes}

Besides E. mamaqucha sp. nov. five additional species of Echinoderes, represented by one specimen each, were identified in the investigated material. One specimen was identified as Echinoderes juliae Sørensen et al. (2018) and one as Echinoderes pterus Yamasaki et al. (2018a,b), whereas the three remaining ones could not be identified with certainty. All three unidentified species share several characters with already described species, but they also showed character traits that made exact identification uncertain. Although they might represent undescribed species, formal descriptions will not be provided since all specimens occurred only as singletons.

\section{Echinoderes juliae Sørensen et al. (2018) (Figure 5 and Table 4)}

Material examined: adult female, collected on March 6, 2018, at station 1, at $2560 \mathrm{~m}$ depth, on abyssal plain, east of the Atacama Trench $\left(23^{\circ} 49^{\prime} \mathrm{S} 70^{\circ} 50^{\prime} \mathrm{W}\right)$ (Figure 1 and Table 1), mounted in Fluoromount-G, deposited at the Natural History Museum of Denmark, under catalog number NHMD-872652.

\section{Brief Description}

Echinoderes with middorsal spines on segments 4 to 8 and spines in lateroventral positions on segments 6 to 9. Tubes present in lateroventral position on segment 5 only. Glandular cell outlets type 2 present in subdorsal, laterodorsal, sublateral and ventrolateral positions on segment 2 , in sublateral positions on segments 3, 4 and 8, and in midlateral positions on segment 5 (Figures 5B-D). Tergal extensions conspicuous long and slender, with long, flexible tips (Figure 5E).

\section{Remarks}

Echinoderes juliae belongs to one of the deep-sea species originally found on the abyssal plain off Oregon and along the continental rise off California, the Northeast Pacific at 2702 to $3679 \mathrm{~m}$ depth (Sørensen et al., 2018). Despite significant geographical distance $(\mathrm{ca} .7000 \mathrm{~km}$ ) between the type locality and the Atacama Trench region, the morphology and morphometrics of the examined specimen are completely in line with the original description of E. juliae in Sørensen et al. (2018) (Figure 5 and Table 4). Differences were detected neither in sensory spots positions nor in glandular cell outlets types 1 and 2 .

\section{Echinoderes pterus Yamasaki et al. (2018a,b) (Figure 6)}

Material examined: adult female, collected on March 28, 2018, at station 9, at $4050 \mathrm{~m}$ depth, on abyssal plain, east of the Atacama Trench $\left(20^{\circ} 20^{\prime} \mathrm{S} 70^{\circ} 59^{\prime} \mathrm{W}\right)$ (Figure 1 and Table 1), mounted in aluminum stub for SEM and stored in the personal collection of MVS.

\section{Brief Description}

Echinoderes with middorsal spines on segments 4 to 8 and spines in lateroventral positions on segments 6 to 9. Tubes present in lateroventral position on segment 5 and in laterodorsal position on segment 10. Characteristic tufts of long hairs present in laterodorsal positions on segment 9. Glandular cell outlets type 2 absent.

\section{Remarks}

Echinoderes pterus is a species with a wide geographic distribution, ranging from the high Arctic, the North Atlantic, and into the Mediterranean Sea (Yamasaki et al., 2018a), and it has also been reported to show a wide bathymetric distribution, from 675 to $4403 \mathrm{~m}$. Besides having this unusually wide range, E. pterus possesses a set of traits that easily distinguishes it from other congeners. The most characteristic is the presence of tufts of hairs on segment 9 - a structure unique for E. pterus. The second feature is the conspicuously thick and long lateroventral 

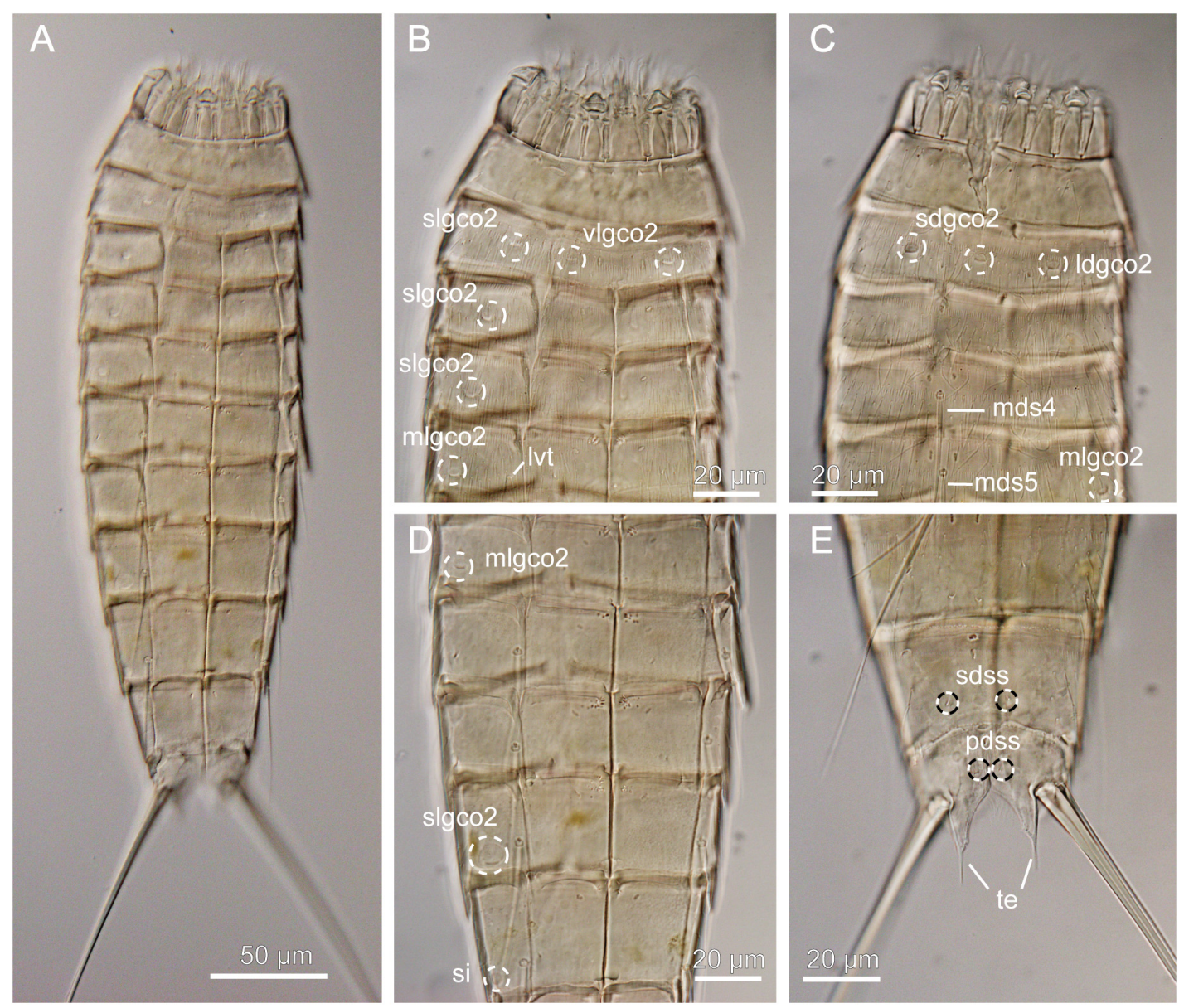

FIGURE 5 | Light micrographs showing overview and details of female Echinoderes juliae (NHMD-872652) collected at station 1. (A) Ventral overview. (B) Segments 1 to 5, ventral view. (C) Segments 1 to 5, dorsal view. (D) Segments 5 to 9, ventral view. (E) Segments 9 to 11, dorsal view. Idgco2, glandular cell outlet type 2; IVt, lateroventral tube; $m d s$, middorsal spine, followed by segment number; mlgco2, glandular cell outlet type 2; pdss, paradorsal sensory spot; sdgco2, subdorsal glandular cell outlet type 2; sdss, subdorsal sensory spot; si, sieve plate; slgco2, sublateral glandular cell outlet type 2; te, tergal extension; vlgco2, ventrolateral glandular cell outlet type 2 .

spines on segment 9, however this character is observed only in the male representatives of the Arctic and North Atlantic populations (Yamasaki et al., 2018a). In the examined material we found only one female specimen, thus lateroventral spines on segment 9 could not be used as a diagnostic character. Exact morphometric details of our specimen are also unavailable because it was mounted for SEM. Nevertheless, the examined specimen possesses the diagnostic key features of $E$. pterus, i.e., the spine and tube pattern and the presence of the tufts of hairs on segment 9 (Figures 6D,G). Moreover, we were able to confirm the presence of almost all sensory spots, according to the original description provided by Yamasaki et al. (2018a); the only exception were sensory spots in paraventral positions on segment 8 and in subdorsal positions on segment 10 that could not be observed due to the mounting position of the examined specimen. In addition to this, our specimen, similar to E. pterus, has long, rather thin cuticular hairs distributed along the body (except segment 1 ), and a primary pectinate fringe with long, thin tips, characteristically curved in the paraventral sectors of segment 1 and 2 (Figure 6, see also Figure 6C in Yamasaki et al., 2018a). Segment 1 is completely hairless, except for hairs associated with the relatively large sensory spots present in subdorsal and laterodorsal positions (Figures 6A,B,E,F), which is also characteristic for the type specimens of E. pterus. Therefore, the identity of the examined specimens seems to be unquestionable.

\section{Echinoderes sp. 1 (Figure 7 and Table 4)}

Material examined: one female, collected on March 8, 2018, at station 6, at $7720 \mathrm{~m}$ depth in the Atacama Trench $\left(24^{\circ} 16^{\prime} \mathrm{S}\right.$ $71^{\circ} 25^{\prime} \mathrm{W}$ ) (Figure 1 and Table 1), mounted in Fluoromount-G, deposited at the Natural History Museum of Denmark, under catalog number NHMD-872653.

\section{Brief Description}

Echinoderes with middorsal spines on segments 6 and 8, and spines in lateroventral positions on segments 6 to 9. Tubes present in ventrolateral positions on segment 2, lateroventral 
TABLE 4 | Measurements from light microscopy of Echinoderes species from the Atacama Trench with comparison of measurements for the closely related species.

\begin{tabular}{|c|c|c|c|c|c|c|c|c|}
\hline Character & $\begin{array}{c}\text { E. juliae present } \\
\text { study }\end{array}$ & $\begin{array}{c}\text { E. juliae } \\
\text { Sørensen et al., } \\
2018\end{array}$ & $\begin{array}{c}\text { Echinoderes sp. } \\
1\end{array}$ & $\begin{array}{c}\text { E. ultraabyssalis } \\
\text { Adrianov and } \\
\text { Maiorova, } 2019\end{array}$ & $\begin{array}{l}\text { Echinoderes sp. } \\
2\end{array}$ & $\begin{array}{c}\text { E. dubiosus } \\
\text { Sørensen et al., } \\
2018\end{array}$ & $\begin{array}{c}\text { Echinoderes sp. } \\
3\end{array}$ & $\begin{array}{c}\text { E. hakaiensis } \\
\text { Herranz et al., } \\
2018\end{array}$ \\
\hline TL & 300 & $285-327$ & 257 & $255-340$ & 278 & $238-281$ & 211 & $266-382$ \\
\hline MSW & 56 & $51-54$ & 59 & $53-60$ & 60 & $60-70$ & 47 & 62 \\
\hline MSW/TL & $18.7 \%$ & $15.6-18.6 \%$ & $23.0 \%$ & $16-22 \%$ & $21.7 \%$ & $22-25 \%$ & $22.3 \%$ & $16-23 \%$ \\
\hline SW-10 & 44 & $41-47$ & 46 & $42-49$ & 51 & $51-57$ & 39 & $46-47$ \\
\hline SW-10/TL & $14.7 \%$ & $12.8-15.4 \%$ & $17.9 \%$ & $13-17 \%$ & $18.6 \%$ & $19-22 \%$ & $18.5 \%$ & $12-17 \%$ \\
\hline MD4 (ac) & 48 & $31-44$ & & & 51 & $30-52$ & 55 & 40 \\
\hline MD5 (ac) & 55 & $42-56$ & & & 56 & $41-78$ & & \\
\hline MD6 (ac) & broken & 59-70 & 59 & $42-51$ & 69 & $64-87$ & 85 & 60 \\
\hline MD7 (ac) & 80 & $67-78$ & & & 113 & 68-93 & & \\
\hline MD8 (ac) & 97 & $71-98$ & 70 & $65-76$ & 193 & $96-136$ & 81 & $75-80$ \\
\hline LV6 (ac) & 47 & $33-43$ & 35 & $31-40$ & 45 & $28-56$ & 26 & $30-31$ \\
\hline LV7 (ac) & 50 & $41-48$ & 39 & $38-42$ & 58 & $32-68$ & 30 & $30-34$ \\
\hline LV8 (ac) & 55 & $44-61$ & 45 & $39-49$ & 74 & 39-91 & 30 & $25-34$ \\
\hline LV9 (ac) & 62 & $40-60$ & 46 & $47-60$ & 94 & $79-120$ & 30 & $27-33$ \\
\hline LTS & 222 & $205-248$ & 234 & $181-205$ & 337 & $186-323$ & 145 & 128 \\
\hline LTS/TL & $74.0 \%$ & $68.8-78.8 \%$ & $91.1 \%$ & $59-73 \%$ & $121 \%$ & $75-118 \%$ & $69 \%$ & $48-33 \%$ \\
\hline LTAS & 126 & $128-133$ & 50 & $42-47$ & 70 & $61-78$ & 49 & $35-38$ \\
\hline
\end{tabular}

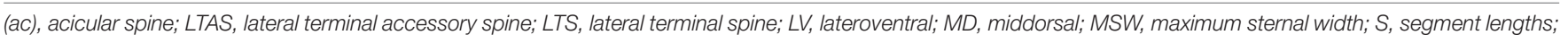
SW-10, standard width, always measured on segment 10; TL, trunk length.

positions on segment 5, lateral accessory positions on segment 8 and laterodorsal positions on segments 9 and 10 .

Adults with head, neck and eleven trunk segments (Figures 7A,D). Overview of measures and dimensions are given in Table 4.

Segments 1 and 2 composed of complete cuticular rings. Segment 1 with glandular cell outlet type 1 in middorsal position and sensory spots in subdorsal and ventrolateral positions (Figure 7C). Posterior margin of this and following nine segments with primary pectinate fringe. Segment 2 with ventrolateral tubes and pair of ventromedial glandular cell outlets type 1 (Figure 7B). No structures observed on the tergal plate. Cuticular hairs on both segments relatively long, distributed around the segments, but covering only the posterior parts. Segments 3 to 11 consist of one tergal and two sternal plates. Pachycycli of anterior segments margins with clear interruptions in middorsal positions and around tergosternal and midsternal junctions (Figures 7A,D). Segments 3 and 4 with ventromedial glandular cell outlet type 1 only; no sensory spots or other traits observed. Segment 5 with lateroventral tube, a pair of sensory spots located midlaterally, and ventromedial glandular cell outlets type 1; similar outlets present at following four segments as well (Figure 7E). Segment 6 with middorsal acicular spine, lateroventral spines, paradorsal, midlateral and ventromedial sensory spots and glandular cell outlets type 1 in paradorsal position (Figures 7D,E). Segment 7 with lateroventral spines, pair of paradorsal and midlateral sensory spots and paradorsal glandular cell outlets type 1 present. Segment 8 with spines in middorsal and lateroventral positions, lateral accessory tubes, paradorsal sensory spots and paradorsal glandular cell outlets type 1 (Figures 7D,E). Segment 9 with lateroventral spines, distinct, long laterodorsal tubes and three pairs of sensory spots, located in paradorsal, subdorsal and ventrolateral positions; small sieve plate located in lateral accessory positions (Figure 7F). Segment 10 with laterodorsal tubes, sensory spot and two glandular cell outlets type 1 located middorsally, and a pair of sensory spots in ventrolateral position. Segment 11 with a pair of very long lateral terminal spines (Figure 7A), nearly reaching trunk length (Table 4). Female with relatively strong and long lateral terminal accessory spines. Sensory spots present in paradorsal positions. A protuberance-like structure emerges between segments 10 and 11 in middorsal position (Figure 7F).

\section{Remarks}

The spine pattern with middorsal acicular spines on segment 6 and 8 is extremely rare among Echinoderes species. This trait is shared only with three species, i.e., E. daenerysae Grzelak and Sørensen (2018) in Grzelak and Sørensen (2018), E. hviidarum Sørensen et al. (2018) and E. ultraabyssalis Adrianov and Maiorova (2019) (Grzelak and Sørensen, 2018; Sørensen et al., 2018; Adrianov and Maiorova, 2019). The latter two are typical deep-water species, described from the Northeast Pacific ( $c a$. $2700 \mathrm{~m}$ water depth) and Northwest Pacific ( $<9000 \mathrm{~m}$ water depth), respectively, while E. daenerysae is known from shallower waters of the Arctic Ocean (100-250 m water depth).

A second very rare feature of Echinoderes sp. 1 is the presence of laterodorsal tubes on segment 9. Interestingly, all three abovementioned species have laterodorsal tubes on this segment, which suggests that these four species might be closely related. The only other species with tubes in this position on the tergal plate is Echinoderes belenae Pardos et al. (2016), but this species cannot in any way be confused with Echinoderes sp. 1 due to the presence of 3 middorsal spines, on segment 4,6 and 8 , 

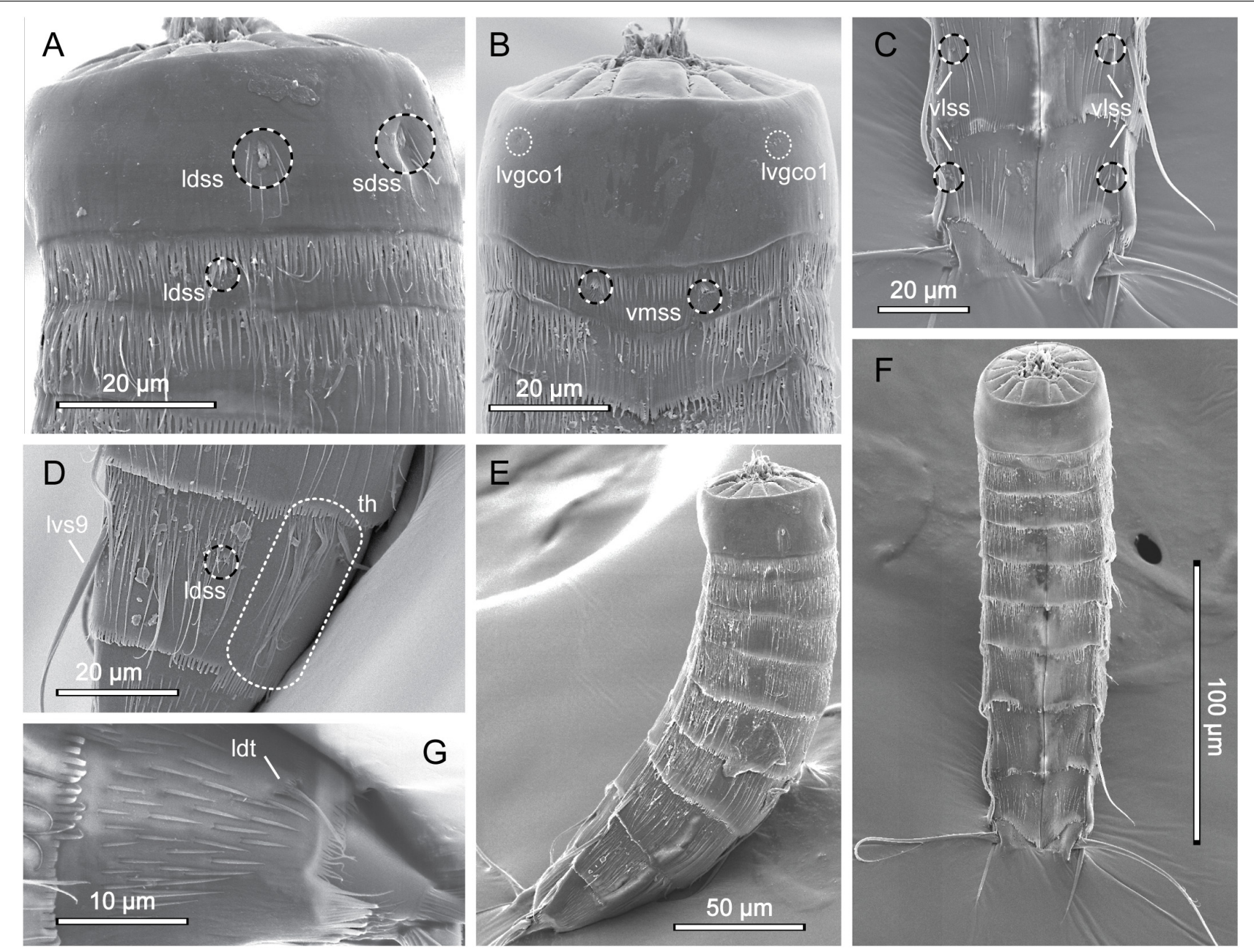

FIGURE 6 | Scanning electron micrographs showing overview and details of female Echinoderes pterus collected at station 9. (A) Segments 1 to 3 , lateral view. (B) Segments 1 to 3, ventral view. (C) Segments 9 to 11, ventral view. (D) Segment 9, lateral view. (E) Lateral overview. (F) Ventral overview. (G) Segment 10, lateral view. Idss, laterodorsal sensory spot; Idt, laterodorsal tube; IVgco1, lateroventral glandular cell outlet type 1; Ivs, lateroventral spine, followed by segment number; sdss, subdorsal sensory spot; th, tuft of hairs; vlss, ventrolateral sensory spot; vmss, ventromedial sensory spot.

numerous tubes in various positions and short lateral terminal spines (Pardos et al., 2016).

Echinoderes sp. 1 shares different features with E. daenerysae, E. hviidarum and E. ultraabyssalis. These include the relatively small body size $(<300 \mu \mathrm{m})$, presence of tubes in lateroventral positions on segment 5 and in lateral accessory positions on segment 8 , as well as long lateral terminal spines and absence of glandular cell outlet type 2. Echinoderes sp. 1 furthermore shares the presence of a middorsal protuberance between segments 10 and 11 with the latter two species. Nevertheless, E. hviidarum is easily distinguished from Echinoderes sp. 1 by the absence of tubes on segment 2. In contrast, E. daenerysae and Echinoderes sp. 1 share the presence of ventrolateral tubes on segment 2 , whereas only $E$. daenerysae has tubes in laterodorsal positions also. Among the three species, E. ultraabyssalis appears to be morphologically closest to Echinoderes sp. 1. This is the deepest kinorhynchs species described so far, and similar to Echinoderes sp. 1, it possesses one pair of tubes, located ventrolaterally on segment 2. Morphometrics of both species also show great resemblance (Table 4), with the exception of the proportions of the lateral terminal spines vs. trunk length. Echinoderes sp. 1 has longer lateral terminal spines, nearly as long as the trunk length $(\mathrm{LTS} / \mathrm{TL}=91 \%)$, while the lateral terminal spines in E. ultraabyssalis are no longer than $2 / 3$ of the trunk length (mean $\mathrm{LTS} / \mathrm{TL}=59 \%$ ). It appears that also the arrangement and number of sensory spots show some differences between these two species. Although only one specimen was available for examination and we cannot exclude the possibility that some sensory spots were missed, we can at least confirm their presence in subdorsal positions on segment 11 and in midlateral positions on segments 5 and 6. None of these were described for E. ultraabyssalis. However, the key character to distinguish Echinoderes sp. 1 from E. ultraabyssalis is the presence of laterodorsal tubes on segment 10. Although the presence of such tubes can be difficult to visualize with LM, the tubes are well visible in Echinoderes sp. 1, while their absence in E. ultraabyssalis was confirmed 

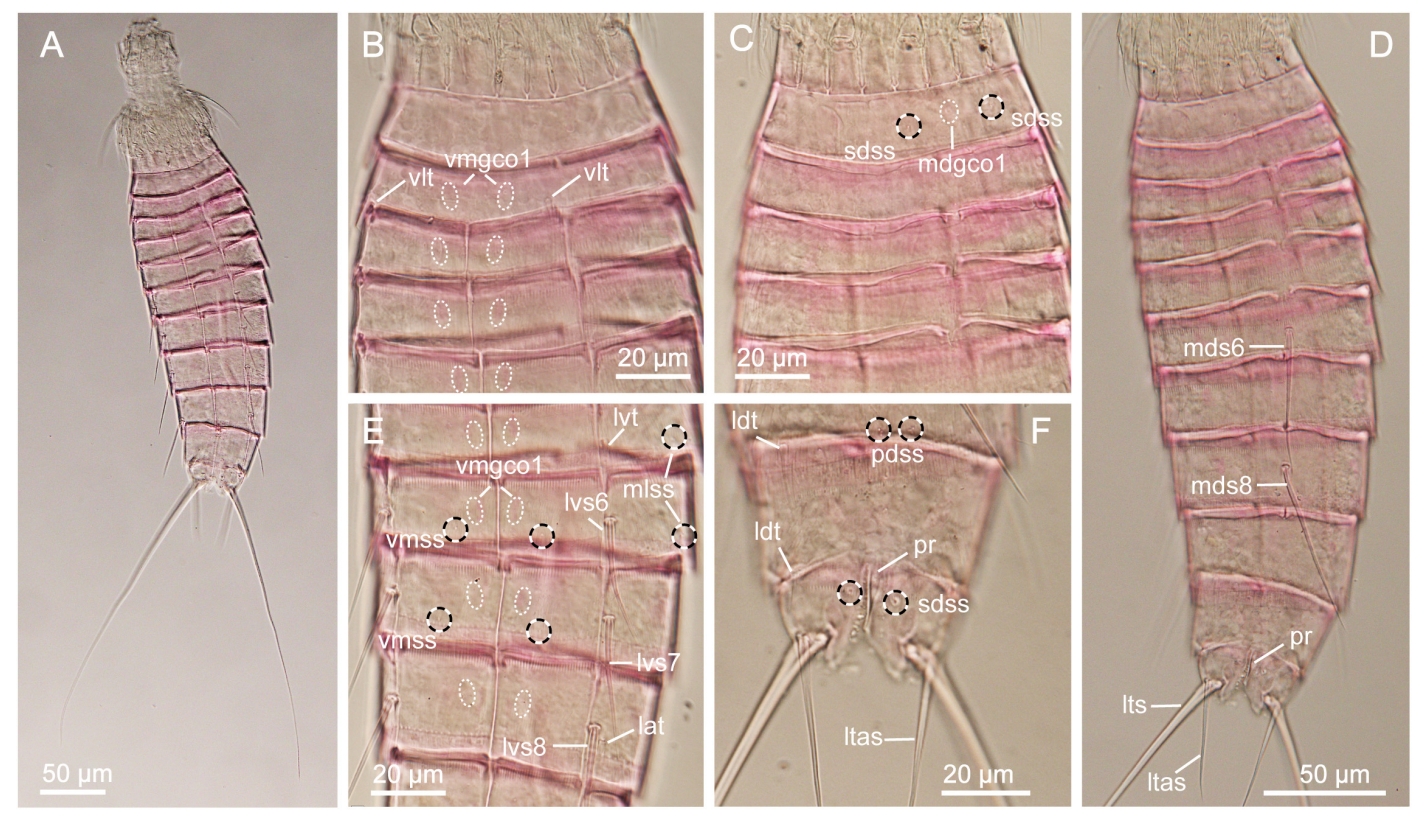

FIGURE 7 | Light micrographs showing overview and details of female Echinoderes sp. 1 (NHMD-872653) collected at station 6. (A) Ventral overview. (B) Segments 1 to 5, ventral view. (C) Segments 1 to 5, dorsal view. (D) Dorsal overview. (E) Segments 5 to 8, ventral view. (F) Segments 9 to 11, dorsal view. lat, lateral accessory tube; Idt, laterodorsal tube; Itas, lateral terminal accessory spine; Its, lateral terminal spine; IVs, lateroventral spine, followed by segment number; IVt, lateroventral tube; $m d g c 01$, middorsal glandular cell outlet type $1 ; \mathrm{mds}$, middorsal spine, followed by segment number; $\mathrm{m} / \mathrm{ss}$, midlateral sensory spot; pdss, paradorsal sensory spot; pr, protuberance; sdss, subdorsal sensory spot; vlt, ventrolateral tube; vmgco1, ventromedial glandular cell outlet type 1; vmss, ventromedial sensory spot.

with SEM (Adrianov and Maiorova, 2019). Therefore, we believe that, even though the differences between Echinoderes sp. 1 and E. ultraabyssalis are subtle, we should consider them as diagnostic until more material becomes available for comparison. It seems clear that the two species are closely related hadal/deepsea trench species.

\section{Echinoderes sp. 2 (Figure 8 and Table 4)}

Material examined: one female, collected on March 20, 2018, at station 7 , at $5500 \mathrm{~m}$ depth in the Atacama Trench $\left(22^{\circ} 56^{\prime} \mathrm{S}\right.$ $71^{\circ} 37^{\prime} \mathrm{W}$ ) (Figure 8 and Table 1), mounted in Fluoromount-G, deposited at the Natural History Museum of Denmark, under catalog number NHMD-872654.

\section{Brief Description}

Echinoderes with middorsal spines on segments 4 to 8 , and spines in lateroventral positions on segments 6 to 9 . Tubes present in lateroventral positions on segment 5 , lateral accessory positions on segment 8 and laterodorsal position on 10 .

Adults with head, neck and eleven trunk segments (Figures 8A,D). Overview of measures and dimensions are given in Table 4.

Segments 1 and 2 composed of complete cuticular rings. Segment 1 with sensory spots in subdorsal and laterodorsal positions, two glandular cell outlets type 1 in middorsal position and pair in ventrolateral positions (Figure 8C). Posterior edge of this and following nine segments with primary pectinate fringe. Segments 2 and 3 without any conspicuous cuticular structures, except for one middorsal glandular cell outlet type 1 (Figure 8B).
Segment 4 with acicular middorsal spine; paradorsal and ventromedial glandular cell outlets types 1 , present on this and following five segments (Figures 8C,F). Segment 5 with acicular spine in middorsal position and tubes in lateroventral positions (Figures 8A,C). Segment 6 with acicular spines in middorsal and lateroventral positions; sensory spots present in midlateral position. Segment 7 with acicular spines in middorsal and lateroventral positions; sensory spots present in ventromedial positions. Segment 8 with acicular spines in middorsal and lateroventral positions; middorsal spine very long, exceeding posterior part of segment 11 (Figure 8A). Tubes present in lateral accessory positions (Figure $\mathbf{8 F}$ ). Sensory spots located in paradorsal positions only, but hardly visible due to the presence of a middorsal papillary flap on the posterior part of the segment (Figure 8E). Segment 9 with long lateroventral spines, which exceed way beyond the terminal segment (Figure 8G). Sensory spots present in paradorsal and ventrolateral positions. Papillary flap, smaller than on preceding segment, present middorsally on the posterior part of the segment (Figure 8E). Rounded, small sieve plates present in lateral accessory positions (Figure $8 \mathrm{~F}$ ). Segment 10 with well visible, relatively long laterodorsal tubes, paradorsal sensory spots and glandular cell outlets type 1 present in middorsal and ventromedial positions. Segment 11 with long lateral terminal spines. Specimen with thick lateral terminal accessory spines. Sensory spots present in subdorsal position. Two glandular cell outlets type 1 located middorsally. Tergal extensions short and pointed/triangular (Figure 8G). The posterior margins of the sternal plates rounded, much shorter than tergal extensions (Figure 8G). 

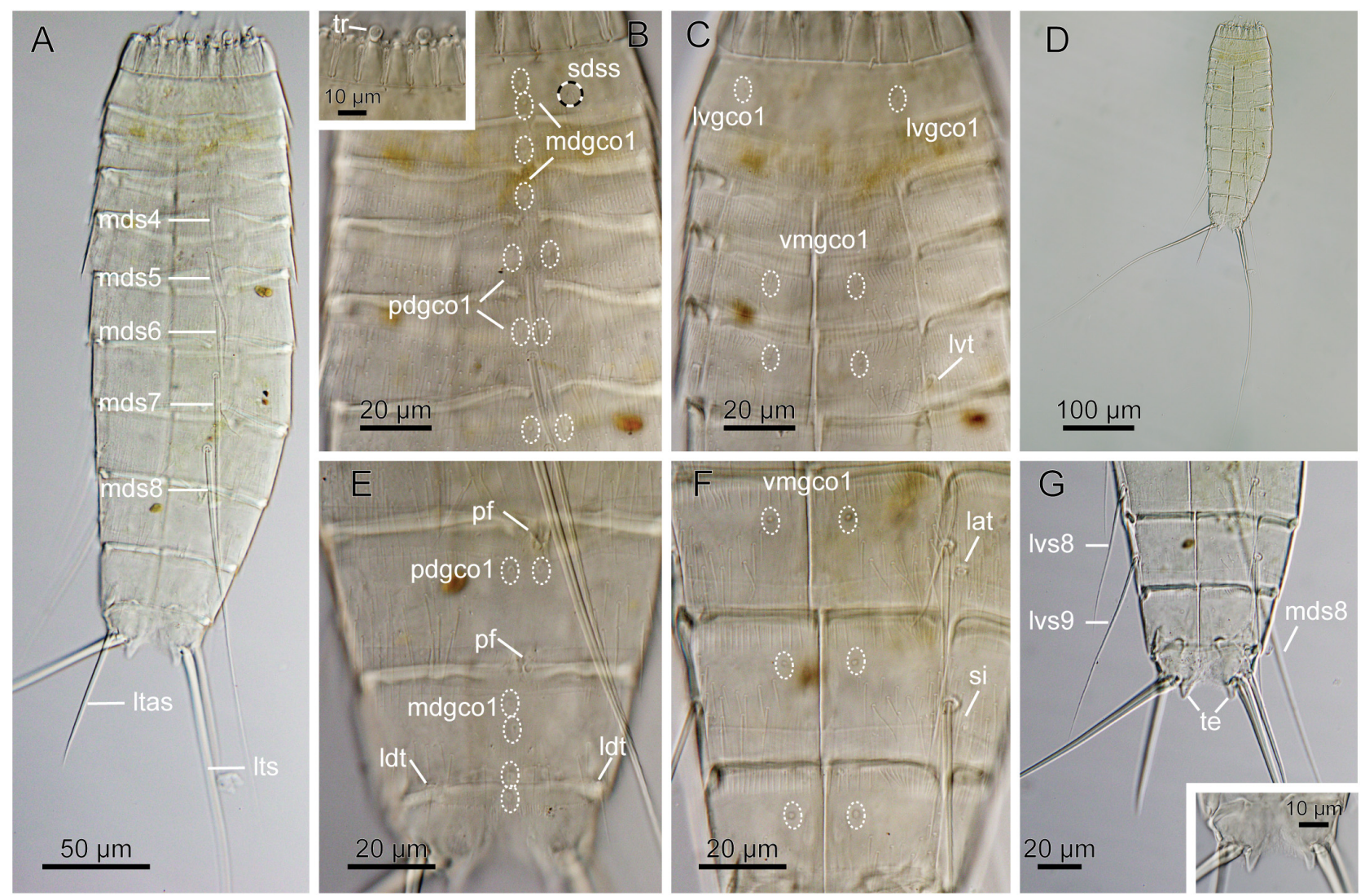

FIGURE 8 | Light micrographs showing overview and details of female Echinoderes sp. 2 (NHMD-872654) collected at station 7. (A) Dorsal overview. (B) Segments 1 to 6 , dorsal view, with close-up showing trichoscalids. (C) Segments 1 to 5 , ventral view. (D) Dorsal overview, showing full length of lateral terminal spines. (E) Segments 8 to 11, dorsal view. (F) Segments 8 to 10, ventral view. (G) Segments 8 to 11, ventral view, with close-up on segment 11 showing tergal extension. lat, lateral accessory tube; Idt, laterodorsal tube; Itas, lateral terminal accessory spine; Its, lateral terminal spine; /vgco1, lateroventral glandular cell outlet type 1; Ivs, lateroventral spine, followed by segment number; / $v t$, lateroventral tube; $m d g c o 1$, glandular cell outlet type 1; mds, middorsal spine, followed by segment number; pdgco1, paradorsal glandular cell outlet type 1; pf, papillary flap; sdss, subdorsal sensory spot; si, sieve plate; te, tergal extension; tr, trichoscalid; vmgco1,

ventromedial glandular cell outlet type 1 .

\section{Remarks}

The spine and tube pattern of Echinoderes sp. 2, with presence of middorsal spines on segments 4 to 8 , tubes/spines in lateroventral positions of segments 5 to 9 , tubes in lateral accessory position on segment 8 and in laterodorsal position on segment 10, is shared with 7 species (Yamasaki et al., 2020), i.e., E. adrianovi, Echinoderes barbadensis Cepeda et al. (2019a), Echinoderes dujardini Claparède (1863), Echinoderes gerardi Higgins (1978), Echinoderes muricatus Pardos et al. (2016), Echinoderes parrai G ${ }^{a}$ Ordóñez et al. (2008), Echinoderes sp. 2 in Yamasaki et al. (2018b) (Higgins, 1978; Ga Ordóñez et al., 2008; Herranz et al., 2014; Pardos et al., 2016; Yamasaki et al., 2018b; Cepeda et al., 2019a; Sørensen et al., 2020). Nevertheless, Echinoderes sp. 2 is unique among the congeners by its absence of tubes or glandular cell outlets type 2 on segment 2. If we do not consider the presence of tubes on segment 8 in the comparison, which sometimes might be difficult to see with LM, Echinoderes sp. 2 may resemble three other species, i.e., Echinoderes kaempfae, E. pterus and Echinoderes stockmani Adrianov (1999) in Adrianov and Malakhov (1999) (Adrianov and Malakhov, 1999; Yamasaki et al., 2018a, 2019). Nevertheless, all species can easily be discriminated from Echinoderes sp. 2. Echinoderes pterus can be distinguished by the presence of the tufts of hairs on segment 9 - a structure unique for this species (see discussion above). Echinoderes stockmani possesses additional pairs of tubes on segments 7 and 9, in laterodorsal and subdorsal positions, respectively. Among the abovementioned species, E. kaempfae appears to be most similar to Echinoderes sp. 2. Echinoderes kaempfae is a deep-sea species, described from $3110 \mathrm{~m}$ depth at the foot of Senghor Seamount in the Northeast Atlantic (Yamasaki et al., 2019). Next to the spines and tubes pattern (with exception of presence/absence of lateral accessory tube on segment 8), Echinoderes sp. 2 and E. kaempfae share the presence of long and thin terminal spines and general appearance/shape of the trunk. However, the two species are conspicuously different in tergal extension shape, which appears significantly longer and more pointed in E. kaempfae. The latter species also 
have shorter spines than Echinoderes sp. 2, both on dorsal and ventral sides.

Echinoderes sp. 2 shows the closest resemblance to the deepsea species E. dubiosus. Although the latter possess glandular cell outlets type 2 on segment 2 that are missing in Echinoderes sp. 2, the two species are conspicuously similar. Both share the same spines patterns on the dorsal and ventral side, the presence of laterodorsal tubes on segment 10, presence of papillary flaps - middorsal structures previously described for only E. dubiosus and E. mamaqucha sp. nov. - and very similar sensory spot distribution patterns. Moreover, both species show great similarity in terms of morphometrics (Table 4). Very long spines, especially lateral terminal spines that are equal or sometimes longer than trunk length, characterize both species (Table 4). However, the middorsal spines on segments 7 and 8 are even longer in Echinoderes sp. 2 compared to those in E. dubiosus. Especially the middorsal spine of segment 8 extends well beyond the terminal segment in Echinoderes sp. 2, opposite to E. dubiosus where it only reaches segment 11 (Sørensen et al., 2018). Echinoderes sp. 2 also has tubes in lateral accessory positions on segment 8, which differs from E. dubiosus that very clearly has its tubes in sublateral positions, leaving a conspicuously larger gap between the tubes and the lateroventral spines. Therefore, based on all abovementioned differences we assume the examined specimen represents an undescribed species. However, since only a single specimen is available, it is too premature to provide a formal description.

\section{Echinoderes sp. 3 (Figure 9 and Table 4)}

Material examined: one female, collected on March 6, 2018, at station 1, at $2560 \mathrm{~m}$ depth on abyssal plain, east of the Atacama Trench $\left(23^{\circ} 49^{\prime} \mathrm{S} 70^{\circ} 50^{\prime} \mathrm{W}\right)$ (Figure 1 and Table 1), mounted in Fluoromount-G, deposited at the Natural History Museum of Denmark, under catalog number NHMD-872651.

\section{Brief Description}

Echinoderes with middorsal spines on segments 4, 6, and 8 , and spines in lateroventral positions on segments 6 to 9. Tubes present in subdorsal, laterodorsal, sublateral and ventrolateral positions on segment 2 , lateroventral position on segment 5 , sublateral position on segment 8 and laterodorsal position on segment 10 .

Adults with head, neck and eleven trunk segments (Figure 9A). Overview of measures and dimensions are given in Table 4.

Segments 1 and 2 composed of complete cuticular rings. Segment 1 with sensory spots in subdorsal and lateroventral positions, glandular cell outlet type 1 in middorsal position and pair located ventrolaterally (Figures 9B,C). Posterior margin of this and following nine segments with primary pectinate fringe, with well-developed, thin and long fringe tips (Figures 9DF). Segment 2 with subdorsal, laterodorsal, sublateral and ventrolateral tubes, single sensory spot and glandular cell outlet type 1 present middorsally and paired glandular cell outlets type 1 located ventromedially (Figures 9B,C). Cuticular hairs on this and following eight segments generally abundant, long, distributed continuously around the segments, except the ventromedial sectors of the segments. Segments 3 to 11 consist of one tergal and two sternal plates. Pachycycli of anterior segments margins with clear interruptions in middorsal positions and around tergosternal and midsternal junctions (Figures 9B-H). Segment 3 with subdorsal sensory spots, single glandular cell outlet type 1 in middorsal position and paired ones in ventromedial positions; ventromedial outlets present at following seven segments as well (Figures 9C,K). Segment 4 with middorsal acicular spine. Glandular cell outlet type 1 observed in paradorsal positions; no sensory spots present. Segment 5 with lateroventral tubes and single middorsal glandular cell outlet type 1. Segment 6 with middorsal acicular spine, lateroventral spines, paradorsal and ventromedial sensory spots and glandular cell outlets type 1 in paradorsal position (Figures 9D,K). Segment 7 with lateroventral spines, pair of ventromedial sensory spots and single middorsal glandular cell outlet type 1 . Segment 8 with spines in middorsal and lateroventral positions, sublateral tubes, paradorsal sensory spots and paradorsal glandular cell outlets type 1 (Figures 9G,H,K). Segment 9 with lateroventral spines, two pairs of sensory spots, located in paradorsal and ventrolateral positions and paradorsal glandular cell outlets type 1; small sieve plate located in lateral accessory positions. Segment 10 with laterodorsal tubes, sensory spot and glandular cell outlet type 1 located middorsally, and pair of sensory spots in subdorsal and ventrolateral positions. Segment 11 with pair of long lateral terminal spines (Figure 9A). Female with relatively strong and long lateral terminal accessory spines (Figure 9A and Table 4). Sensory spots present in subdorsal position; two glandular cell outlets type 1 located middorsally. Tergal extensions short and pointed, with two small serrations at the posterior inner margin (Figure 9J).

\section{Remarks}

Echinoderes sp. 3 resembles Echinoderes hakaiensis described by Herranz et al. (2018) from 88-140 m depth at Calvert Island, British Columbia, and subsequently found at markedly greater depth, $2719 \mathrm{~m}$, off the United States west coast (Herranz et al., 2018; Sørensen et al., 2018). There is no other species with acicular spines in middorsal position on segments 4,6 and 8 and four pairs of tubes on segment 2 . In addition, both species share the presence of tubes on segment 8 in sublateral position, the positions of several glandular cell outlets type 1 and sensory spots, as well as shape of tergal extensions. Nevertheless, we did not assign Echinoderes sp. 3 to E. hakaiensis because of some morphological differences between two species. Considering the wide bathymetrical and geographical distance between British Columbia and the Atacama Trench region and the fact that only a single specimen was available for investigation, we cannot be sure whether observed morphological discrepancies result solely from inter-population variations or indicate two, closely related species. The major difference between Echinoderes sp. 3 and E. hakaiensis are morphometric details. Echinoderes sp. 3 is markedly smaller in trunk length than E. hakaiensis (TL: $211 \mu \mathrm{m}$ vs. $324 \mu \mathrm{m}$, respectively), but has significantly longer middorsal spines on segments 4 and 6 (MDS4: $55 \mu \mathrm{m}$ and MDS6: $85 \mu \mathrm{m}$ in Echinoderes sp. 3, whereas MDS: $40 \mu \mathrm{m}$ and MDS: $60 \mu \mathrm{m}$ in E. hakaiensis) and longer lateral terminal spines (LTS: $145 \mu \mathrm{m}$ 


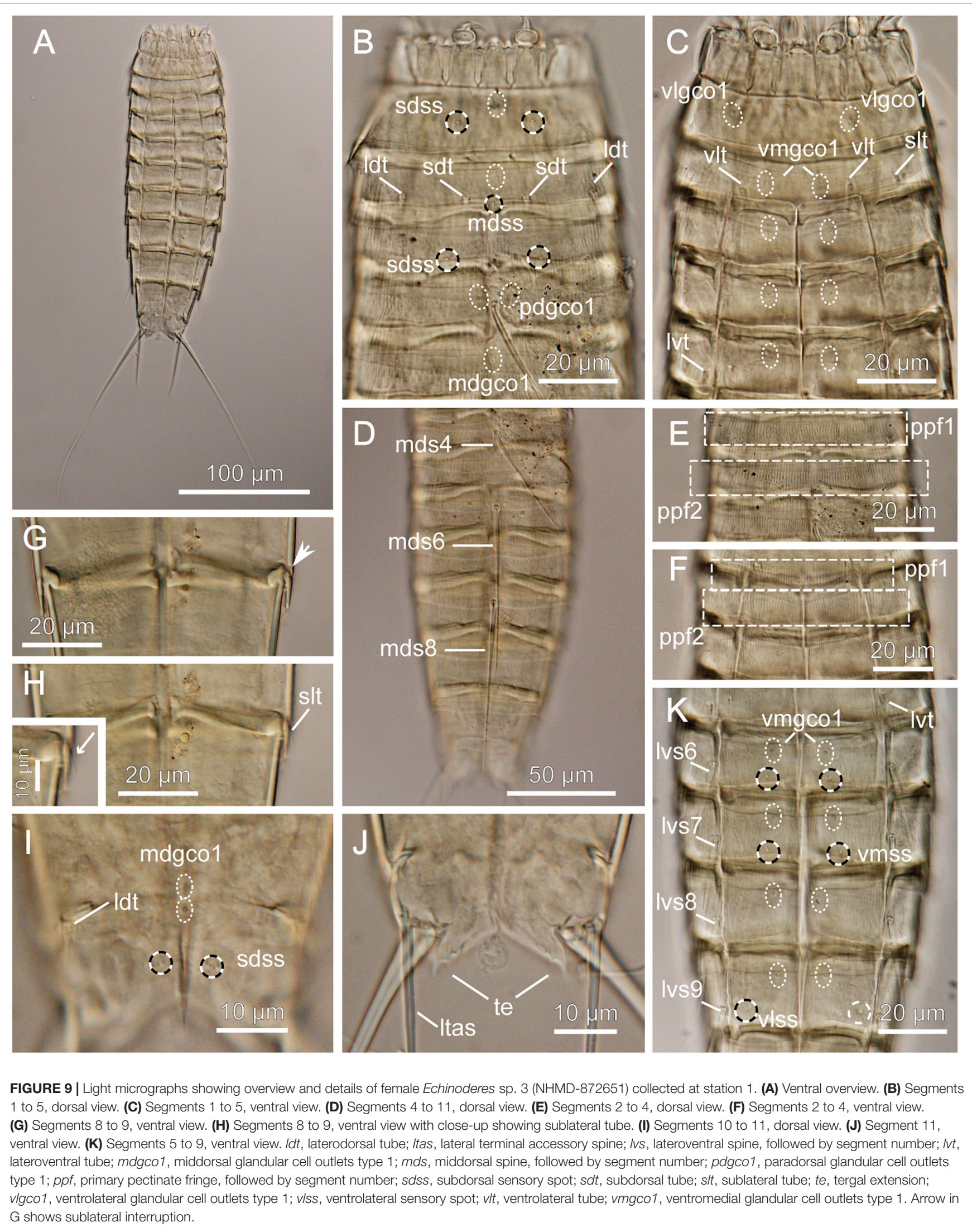


vs. $128 \mu \mathrm{m}$ ) (Table 4). Differences in trunk and lateral terminal spine lengths result in higher TL/LTS ratio in Echinoderes sp. 3 in comparison to E. hakaiensis (TL/LTS: 69 vs. 40\%, respectively). In Echinoderes sp. 3 the pectinate fringe tips of the primary pectinate fringe on segments 1 and 2 are long and thin, both on the dorsal and ventral side (Figures 9E,F), whereas the pectinate fringe tips in E. hakaiensis are much shorter and less-developed, almost absent in the ventral sector of segment 2 (see Figure $12 \mathrm{C}$ in Herranz et al., 2018). Another character that makes Echinoderes sp. 3 differ from E. hakaiensis is the presence of laterodorsal tubes on segment 10 in the female. Although tubes in this position were observed in male representatives of E. hakaiensis, their absence in female was confirmed with SEM (Herranz et al., 2018). In the investigated specimen, the tubes are difficult to visualize, but they are certainly present (Figure 9I). Abovementioned differences leave it uncertain whether the examined specimen is identical with E. hakaiensis, but since only a single specimen is available, we hesitate to describe the species as a new species.

\section{DISCUSSION}

Nearly $75 \%$ of the seafloor is at abyssal and hadal depths (> $3000 \mathrm{~m}$ ) making it the largest benthic habitat globally (Harris et al., 2014). However, our understanding of the lowerabyssal and particularly the hadal zones $(>6000 \mathrm{~m})$ is still very much in its initial stage. Trench biology represents a major frontier in deep-sea studies and the fauna inhabiting these regions probably represents the least understood communities in our ocean (Blankenship-Williams and Levin, 2009). The present study provides the first overview of mud dragon species inhabiting the Atacama Trench and adjacent abyssal and bathyal depths. Our material revealed six species of Echinoderes. Of these, Echinoderes mamaqucha sp. nov. is described as a new species and morphological data of three undescribed species are given. Moreover, two already known species, i.e., Echinoderes juliae and Echinoderes pterus were recovered.

\section{Abundance and Species Richness in Hadal Zone}

It seems to be a general trend that benthic abundance decreases with increasing water depth (Rex et al., 2006; Wei et al., 2010). Nonetheless, studies conducted in hadal trenches have revealed relatively abundant benthic communities, particularly meiofauna (Danovaro et al., 2002; Schmidt and Martínez Arbizu, 2015; Leduc et al., 2016). Many hadal trenches are close to land and receive organic inputs from terrestrial and coastal sources, increasing microbial activity (Wenzhöfer et al., 2016; Glud et al., 2021) and supporting higher benthic densities than expected for greater depths (Danovaro et al., 2002; Jamieson et al., 2010). In addition, the persistent rain of particulate organic matter (POM) from the surface layers is deposited along the trench axis (von Huene and Scholl, 1991; Turnewitsch et al., 2014). Among others, the Atacama Trench underlies one of the most productive surface waters, which results in high total trench POC flux (Steward and Jamieson, 2018; Glud et al., 2021), reduced sediment grain size and exceptionally high meiofaunal abundance at hadal depths $(7800 \mathrm{~m})$ (Danovaro et al., 2002). As reported by Danovaro et al. (2002), abundance of all meiofauna taxa were notably higher at hadal station in comparison with bathyal depths, and this trend also includes the kinorhynchs $(0.2 \pm 0.3$ and $46 \pm 40$ ind./10 $\mathrm{cm}^{2}$, at 1050 and $7800 \mathrm{~m}$, respectively). In our study, the abundance of kinorhynchs recorded at trench stations was not as high as reported in the previous study by Danovaro et al. (2002) $\left(5.7 \pm 2.7\right.$ ind./10 $\left.\mathrm{cm}^{2}\right)$, but a clear increase in mud dragons abundance with water depth was observed (Figure 10). The highest number of individuals in the deepest station (Figure 10), is in accordance with observations for other trenches (Schmidt and Martínez Arbizu, 2015; Leduc et al., 2016). The steep slopes of the trenches create a gravity-driven downward transport and therefore elevated deposition of organic matter and intensified microbial metabolism, which support high faunal standing stocks at the greatest depth of hadal trenches (Danovaro et al., 2003; Glud et al., 2013).

Even though they are rich in terms of abundance and/or biomass, hadal benthic communities are rather poor in number of species. Moreover, a high degree of endemism is attributed to the hadal fauna as a whole and also within each trench (Wolff, 1960; Belyaev, 1989; Eustace et al., 2016), although, the selective pressures driving such picture remains unclear. Physical/geographical isolation, sufficiently different environmental conditions experienced by each trench and/or geological age of the trench habitats are considered to be major contributing factors to low species diversity and high endemism of trench bottom fauna (Jamieson et al., 2010). Interestingly, the kinorhynch community at the Atacama Trench hadal stations was dominated by a single species, namely. E. mamaqucha sp. nov. that occurred at all six sites along the trench axis and was present almost exclusively at hadal depths (Figure 10 and Table 1). The only exception was the abyssal station at 5550 $\mathrm{m}$, where a single specimen of E. mamaqucha sp. nov. was found. Stations at the trench floor extend across $>400 \mathrm{~km}$, but the north-south alignment of the trench axis probably acts as dispersal corridor and thereby facilitates similarity among the kinorhynch fauna along a longitudinal gradient. A similar picture was obtained from an amphipod study at hadal depths in the Atacama Trench (Perrone et al., 2002), where only one undescribed species was documented. A single dominating amphipod species at hadal depths was also found in northwest Pacific trenches (Kuril-Kamchatka, Japan, Izu-Bonin, Mariana, and Philippine trenches; Kamenskaya, 1981; France, 1993) and southwest Pacific trenches (Kermadec and Tonga trenches; Blankenship et al., 2006). This could suggest that E. mamaqucha sp. nov. likewise represents an endemic hadal mud dragon form for the Atacama Trench. This assumption should be taken with caution though, since our knowledge of the distribution of microscopic marine animals suffers from lack of data and sampling bias (Boakes et al., 2010) and assessing true biogeographical ranges or distribution patterns is very challenging, especially for a group such as kinorhynchs.

\section{Hadal vs. Abyssal and Bathyal Depths}

It is noteworthy that the mud dragon species observed at the trench floor differed from those collected at the surrounding 


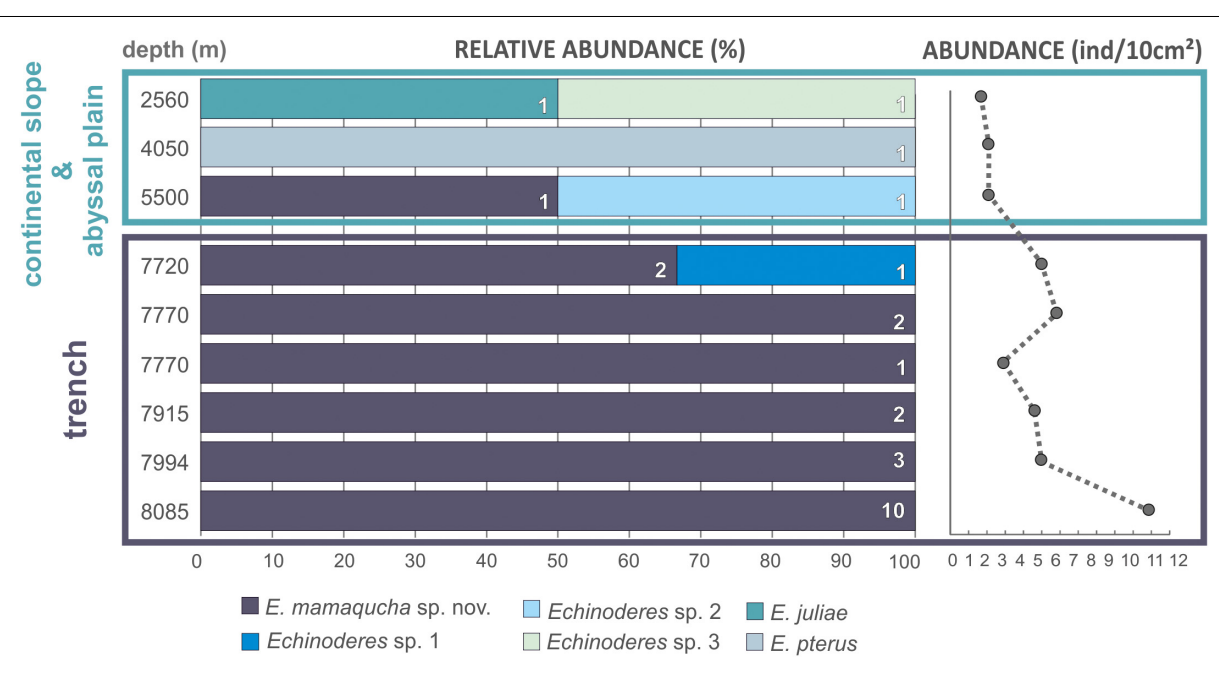

FIGURE 10 | Bathymetric distribution of Echinoderes spp. (left side of the plot) and total abundance of kinorhynchs (right side of the plot) collected along the Atacama Trench hadal zone, adjacent abyssal plain and continental slope.

abyssal plain and continental slope (Figure 10 and Table 1). Even though, abundance of kinorhynchs was very low and small sample size might have important implication on the assessment of kinorhynchs diversity, our results are in line with other hadal studies. It has already been documented that trenches and their adjacent abyssal plain can differ significantly in their macrobenthic (Jamieson et al., 2011; Fujii et al., 2013; Gallo et al., 2015) and meiobenthic communities (Kitahashi et al., 2013; Leduc et al., 2016; Schmidt et al., 2019), due to the combination of environmental conditions at trenches floor that are not found in any other deep-sea environment. However, these geographical and depth gradients do not act as sharp boundaries but rather as transitional zones (Jamieson et al., 2011), thus still the hadal zone can share few fauna species with abyssal communities, but less likely with bathyal ones (Eustace et al., 2016; Brandt et al., 2019). The precise depth at which this transition occurs is expected to be trench-specific (Fujii et al., 2013; Schmidt and Martínez Arbizu, 2015), and may vary within trenches. Our results seem to fit well with these previous observations, as species turnover between hadal, abyssal and bathyal depths can be clearly noted (Figure 10). Individuals of E. mamaqucha sp. nov. dominated at the hadal zone, sediments of abyssal stations were inhabited by E. pterus, Echinoderes sp. 2 and E. mamaqucha sp. nov., while E. juliae and Echinoderes sp. 3 were found at the shallower station located at the continental slope. Nevertheless, it should also be noted, that all mud dragon species of the Atacama Trench region belong to one genus Echinoderes. Echinoderes is the most common, widely distributed and species-rich mud dragon genus. However, from the currently 24 known abyssal mud dragon species, only 11 belong to Echinoderes, which indicates that the generic diversity of deep-sea kinorhynchs is higher than it would seem to be, given our results. On the other hand, a very extensive study performed on the northeastern Pacific clearly showed that the deep-sea kinorhynch fauna in this region is dominated by echinoderids (Sørensen et al., 2018). It is therefore difficult to predict whether the observed diversity pattern, with representatives of only one mud dragon genus, reflects limitation in the data or low diversified kinorhynch community, distinctive for the Atacama Trench region. A lack of characterization of Kinorhyncha communities across the Pacific abyssal plain makes it difficult to assess the geographic distribution of deepsea forms.

\section{Community Composition and Comparison With Other Deep-Sea Species}

What should be highlighted though, is that the newly described species (E. mamaqucha sp. nov.) as well as the other three potentially new species (Echinoderes sp. 1, Echinoderes sp. 2, and Echinoderes sp. 3) show a very close resemblance to other deep-water species of Echinoderes. Echinoderes mamaqucha sp. nov. and Echinoderes sp. 2 show a close similarity to E. dubiosus that was described from the North-Eastern Pacific (> $3500 \mathrm{~m}$ water depth) (Sørensen et al., 2018) and E. bathyalis described from the East Atlantic (> $2500 \mathrm{~m}$ water depth) (Yamasaki et al., 2018b). The second striking morphological similarity can be noted between the specimen of Echinoderes sp. 1 found at $7720 \mathrm{~m}$ and E. ultraabyssalis described from the deepest depression of the Kuril-Kamchatka Trench (> 9000 m; Adrianov and Maiorova, 2019). In other words, even though each trench and surrounding abyssal plains seem to host a unique fauna at the species level, there is still a close phylogenetic relationship between the species at these extreme depths. This either suggests a certain gene flow between these deep habitats, or that they originally were invaded by a few species that subsequently speciated further. The potential of gene flow of pan-oceanic scale has been already documented for some benthic deepsea taxa (Eustace et al., 2016; LaBella et al., 2017), including meiofaunal organisms (Pawlowski et al., 2007; Bik et al., 2010; 
Fontaneto, 2019 and references therein). Hence, similarities between geographically distinct species is highly possible, as a result of incomplete lineage sorting following the historicaltectonic movements (e.g., formation of the Isthmus of Panama) or dispersal over large distance, e.g., through thermohaline circulation (Pawlowski et al., 2007; Ptatscheck and Traunspurger, 2020). The latter may seem even more likely, as in the material from abyssal station at $4050 \mathrm{~m}$ we found E. pterus. This species was already noted at several locations in the Arctic Ocean, in the North Atlantic and the Mediterranean, from the continental shelf to the deep-sea floor and on seamounts (Yamasaki et al., 2018a, 2019). A similar example is the presence of E. juliae and Echinoderes sp. 3 in the sediments collected from continental slope station at $2560 \mathrm{~m}$. Echinoderes juliae is known from the abyssal plain and continental rise off California (Sørensen et al., 2018) and despite significant geographical distance (ca. $7000 \mathrm{~km}$ ) we found considerable consistency of morphological characters between E. juliae at its type locality and the individual from the Atacama Trench region. In contrast, Echinoderes sp. 3 shows close morphological resemblance to E. hakaiensis a species described from British Columbia (Herranz et al., 2018) and later found in the deep-water off California (Sørensen et al., 2018). These findings support the previous suggestions about the capability of deep-sea kinorhynchs species to disperse over great distances (Neuhaus and Sørensen, 2013; Sørensen et al., 2018; Yamasaki et al., 2018a, 2019). Yet, the distribution process, the ongoing dispersal directions and migration routes are unknown.

Hadal trenches remain among the least sampled deepsea habitats, although their unusual isolation and distribution offer exceptional opportunities to test many ecological and evolutionary theories (Blankenship-Williams and Levin, 2009). Therefore, we hope that this first evaluation of mud dragon diversity in the Atacama Trench add to other hadal studies providing new information about species diversity, which at last will enhance our understanding of biodiversity patterns in the deep-sea.

\section{DATA AVAILABILITY STATEMENT}

The original contributions presented in the study are included in the article/supplementary materials, further inquiries can be directed to the corresponding author/s.

\section{REFERENCES}

Adrianov, A. V., and Maiorova, A. S. (2015). Pycnophyes abyssorum sp. n. (Kinorhyncha: Homalorhagida), the deepest kinorhynch species described so far. Deep Sea Res. II Top. Stud. Oceanogr. 111, 49-59. doi: 10.1016/j.dsr2.2014. 08.009

Adrianov, A. V., and Maiorova, A. S. (2016). Condyloderes kurilensis sp. nov. (Kinorhyncha: Cyclorhagida) - a new deep water species from the abyssal plain near the Kuril-Kamchatka Trench. Russ. J. Mar. Biol. 42, 11-19. doi: 10.1134/ s1063074016010028

Adrianov, A. V., and Maiorova, A. S. (2018a). Meristoderes okhotensis sp. nov. the first deep-water representative of kinorhynchs in the Sea of Okhotsk

\section{AUTHOR CONTRIBUTIONS}

KG acquired the funding for taxonomic studies, performed morphological examinations and taxonomic work, and prepared the original draft and figures. DZ conceived the general idea of the study and acquired the funding for the deep-sea cruise. MSh processed meiofauna samples. MSø conceived the general idea of the taxonomic study, supervised morphological and taxonomic studies, and manuscript writing. All authors proof-read the manuscript prior to submission, contributed to the final version and approved the submitted version.

\section{FUNDING}

This study was funded by the project "Prokaryote-nematode Interaction in marine extreme envirONments: a uniquE source for ExploRation of innovative biomedical applications" (PIONEER) funded by the Total Foundation and IFREMER (2016-2019). Financial support was also provided through the European Research Council (HADES-ERC Project Grant No. 669947) and by the Danish National Research Foundation (Grant No: DNRF145, Danish Center for Hadal Research, HADAL). The first author was supported by the Polish National Agency for Academic Exchange NAWA, the Bekker Programme Fellowship (PPN/BEK/2019/1/00160/00001) at Natural History Museum of Denmark and partly by the statutory funds from the Institute of Oceanology, Polish Academy of Sciences (IO PAN).

\section{ACKNOWLEDGMENTS}

We are indebted to Ronnie Glud (SDU) for the invitation to work on Atacama meiofauna. Special thanks go to the chief scientists (Ronnie Glud/SDU, Frank Wenzhöfer/AWI, and Matthias Zabel/MARUM), captain, and crews of the cruise SO261 (R/V SONNE, 02/03-02/04/18). We thank Sophie Arnaud and Miriam Brandt for support during sampling activities. We would also like to thank Nuria Sánchez (Ifremer/UCM) for help in preparation of animals, Nicolas Gayet (Ifremer) for help in the SEM preparation, Eve Julie Pernet (Ifremer) for support in the laboratory, and Emilia Trudnowska (IOPAN) for help with map preparation. This article is registered at www.zoobank. org under urn:lsid:zoobank.org:pub:1A9867FF-1C58-F17-A869F7534B262518.

(Kinorhyncha: Cyclorhagida). Deep Sea Res. II Top. Stud. Oceanogr. 154, 99105. doi: 10.1016/j.dsr2.2017.10.011

Adrianov, A. V., and Maiorova, A. S. (2018b). Parasemnoderes intermedius gen. n., sp. n. - the first abyssal representative of the family Semnoderidae (Kinorhyncha: Cyclorhagida). Russ. J. Mar. Biol. 44, 355-362. doi: 10.1134/ s1063074018050024

Adrianov, A. V., and Maiorova, A. S. (2019). Echinoderes ultraabyssalis sp. nov. from the Kuril-Kamchatka Trench - the first hadal representative of the Kinorhyncha (Kinorhyncha: Cyclorhagida). Prog. Oceanogr. 178:102142. doi: 10.1016/j.pocean.2019.102142

Adrianov, A. V., and Malakhov, V. V. (1999). Cephalorhyncha of the World Ocean. Moscow: KMK Scientific Press. (in Russian with English translation). 
Belyaev, G. M. (1989). Deep-sea Ocean Trenches and Their Fauna. Moscow: Nauka Publishing House.

Bik, H. M., Thomas, W. K., Lunt, D. H., and Lambshead, P. J. D. (2010). Low endemism, continued deep-shallow interchanges, and evidence for cosmopolitan distributions in free-living marine nematodes (order Enoplida). Evol. Biol. 10:1e10.

Blankenship, L. E., Yayanos, A. A., Cadien, D. B., and Levin, L. A. (2006). Vertical zonation patterns of scavenging amphipods from the hadal zone of the Tonga and Kermadec Trenches. Deep-Sea Res. I 53, 48-61. doi: 10.1016/j.dsr.2005. 09.006

Blankenship-Williams, L. E., and Levin, L. A. (2009). Living deep: a synopsis of hadal trench ecology. Mar. Technol. Soc. J. 43, 137-143. doi: 10.4031/mtsj. 43.5.23

Boakes, E. H., McGowan, P. J. K., Fuller, R. A., Chang-qing, D., Clark, N. E., O'Connor, K., et al. (2010). Distorted views of biodiversity: spatial and temporal bias in species occurrence data. PLoS Biol. 8:e1000385. doi: 10.1371/journal. pbio. 1000385

Brandt, A., Alalykina, I., Brix, S., Brenke, N., Błażewicz, M., Golovan, O. A., et al. (2019). Depth zonation of Northwest Pacific deep- sea macrofauna. Prog. Oceanogr. 176:102131. doi: 10.1016/j.pocean.2019.102131

Carus, J. V. (1885). Prodromus Faunae Mediterraneae sive Descriptio Animalium maris Mediterranei incolarum Quam Comparata Silva Rerum Quatenus Innotiut Adiectis et Nominibus Vulgaribus Eorumque Auctoribus in Commodum Zoologorum, Vol. I, Coelenterata, Echinodermata, Vermes, Arthropoda. Germany: E. Schweizerbarfsche Verlagshandlung.

Cepeda, D., Pardos, F., and Sánchez, N. (2019a). Kinorhyncha from the Caribbean, with the description of two new species from Puerto Rico and Barbados. Zool. Anz. 282, 127-139. doi: 10.1016/j.jcz.2019.05.014

Cepeda, D., Sánchez, N., and Pardos, F. (2019b). First extensive account of the phylum Kinorhyncha from Haiti and the Dominican republic (Caribbean Sea), with the description of four new species. Mar. Biodivers. 49, 2281-2309. doi: 10.1007/s12526-019-00963-x

Claparède, A. R. E. (1863). Zur Kenntnis Der Gattung Echinoderes Duj. Beobachtungen über Anatomie und Entwicklungsgeschichte Wirbelloser Thiere an der Küste von Normandie Angestellt. Leipzig: Engelmann

Dal Zotto, M., and Todaro, M. A. (2016). Kinorhyncha from Italy, a revision of the current checklist and an account of the recent investigations. Zool. Anz. 265, 90-107. doi: 10.1016/j.jcz.2016.01.004

Danovaro, R., Gambi, C., and Della Croce, N. (2002). Meiofauna hotspot in the Atacama Trench, eastern south Pacific Ocean. Deep Sea Res. I 49, 843-857. doi: 10.1016/s0967-0637(01)00084-x

Danovaro, R., Della Croce, N., Dell'Anno, A., and Pusceddu, A. (2003). A depocenter of organic matter at $7800 \mathrm{~m}$ depth in the SE Pacific Ocean. Deep Sea Res. I 50, 1411-1420. doi: 10.1016/j.dsr.2003.07.001

Eustace, R. M., Kilgallen, N. M., Ritchie, H., Piertney, S. B., and Jamieson, A. J. (2016). Morphological and ontogenetic stratification of abyssal and hadal Eurythenes gryllus (Amphipoda: Lysianassidae) from the Peru-Chile Trench. Deep Sea Res. Part I 109, 91-98. doi: 10.1016/j.dsr.2015.11.005

Fontaneto, D. (2019). Long-distance passive dispersal on microscopic aquatic animals. Movement Ecol. 7:10.

Fujii, T., Kilgallen, N. M., Rowden, A. A., and Jamieson, A. J. (2013). Deep sea amphipod community structure across abyssal to hadal depths in the PeruChile and Kermadec trenches. Mar. Ecol. Prog. Ser. 492, 125-138. doi: 10.3354/ meps 10489

Fossing, H., Gallardo, V. A., Jørgensen, B. B., Hüttel, M., Nielsen, L. P., and Schulz, H. (1995). Concentration and transport of nitrate by mat-forming sulphur bacterium Thioploca. Nature 374, 713-715. doi: 10.1038/374713a0

France, S. C. (1993). Geographic variation among three isolated populations of the hadal amphipod Hirondellea gigas (Crustacea: Amphipoda: Lysianassoidea). Mar. Ecol. Prog. Ser. 92, 277-287. doi: 10.3354/meps09 2277

Gallo, N. D., Cameron, J., Hardy, K., Fryer, P., Bartlett, D. H., and Levin, L. A. (2015). Submersible- and lander-based community patterns in the Mariana and New Britain trenches: influence of productivity and depth on epibenthic and scavenging communities. Deep Sea Res. I 99, 119-133. doi: 10.1016/j.dsr.2014. 12.012

Gambi, C., Vanreusel, A., and Danovaro, R. (2003). Biodiversity of nematode assemblages from deep-sea sediments of the Atacama Slope and Trench (South
Pacific Ocean). Deep Sea Res. I 50, 103-117. doi: 10.1016/s0967-0637(02) 00143-7

Ga Ordóñez, D., Pardos, F., and Benito, J. (2008). Three new Echinoderes (Kinorhyncha, Cyclorhagida) from north Spain, with new evolutionary aspects in the genus. Zool. Anz. 247, 95-111. doi: 10.1016/j.jcz.2007.07.001

Glud, R. N., Wenzhöfer, F., Middelboe, M., Oguri, K., Turnewitsch, R., Canfield, D. E., et al. (2013). High rates of microbial carbon turnover in sediments in the deepest oceanic trench on Earth. Nat. Geosci. 6, 284-288. doi: 10.1038/ ngeo 1773

Glud, R. N., Berg, P., Thamdrup, B., Larsen, M., Stewart, H. A., Jamieson, J., et al. (2021). Hadal trenches are dynamic hotspots for early diagenesis in the deep sea. Commun. Earth Environ. 2:21.

Grzelak, K., and Sørensen, M. V. (2018). New species of Echinoderes (Kinorhyncha: Cyclorhagida) from Spitsbergen, with additional information about known Arctic species. Mar. Biol. Res. 14, 113-147. doi: 10.1080/17451000.2017. 1367096

Grzelak, K., and Sørensen, M. V. (2019a). Diversity and community structure of kinorhynchs around Svalbard: first insights into spatial patterns and environmental drivers. Zool. Anz. 282, 31-43. doi: 10.1016/j.jcz.2019. 05.009

Grzelak, K., and Sørensen, M. V. (2019b). Diversity and distribution of Arctic Echinoderes species (Kinorhyncha: Cyclorhagida), with description of one new species and redescription of E. arlis Higgins, 1966. Mar. Biodivers. 49, 11311150. doi: 10.1007/s12526-018-0889-2

Harris, P. T., Macmillan-Lawler, M., Rupp, J., and Baker, E. K. (2014). Geomorphology of the oceans. Mar. Geol. 352, 4-24. doi: 10.1016/j.margeo. 2014.01.011

Herranz, M., Sánchez, N., Pardos, F., and Higgins, R. P. (2014). New Kinorhyncha from Florida coastal waters. Helgol. Mar. Res. 68, 59-87. doi: 10.1007/s10152013-0369-9

Herranz, M., Yangel, E., and Leander, B. (2018). Echinoderes hakaiensis sp. nov.: a new mud dragon (Kinorhyncha, Echinoderidae) from the northeastern Pacific Ocean with the redescription of Echinoderes pennaki Higgins, 1960. Mar. Biodivers. 48, 303-325. doi: 10.1007/s12526-0170726-Z

Higgins, R. P. (1978). Echinoderes gerardi n. sp. and E. riedli (Kinorhyncha) with descriptions of closely related species. Trans. Am. Microsc. Soc. 97, 171-180. doi: $10.2307 / 3225589$

Jamieson, A. J., Fujii, T., Mayor, D. J., Solan, M., and Priede, I. G. (2010). Hadal trenches: the ecology of the deepest places on Earth. Trends Ecol. Evol. 25, 190-197. doi: 10.1016/j.tree.2009.09.009

Jamieson, A. J., Kilgallen, N. M., Rowden, A. A., Fujii, T., Horton, T., Lörz, A. N., et al. (2011). Bait-attending fauna of the Kermadec Trench, SW Pacific Ocean: evidence for an ecotone across the abysal-hadal transition zone. Deep Sea Res. I 58, 49-62. doi: 10.1016/j.dsr.2010.11.003

Kamenskaya, O. E. (1981). The amphipods (Crustacea) from deep-sea trenches in the western part of the Pacific Ocean. Trudy Instituta Okeanologii 115, 94-107. (in Russian with English summary).

Karling, T. G. (1954). Echinoderes levanderi n. sp. (Kinorhyncha) aus der Ostsee. Arkiv för Zoologi 7, 189-192.

Kitahashi, T., Kawamura, K., Kojima, S., and Shimanaga, M. (2013). Assemblages gradually change from bathyal to hadal depth: a case study on harpacticoid copepods around the Kuril Trench (north-west Pacific Ocean). Deep Sea Res. I 74, 39-47. doi: 10.1016/j.dsr.2012.12.010

LaBella, A. L., Van Dover, C. L., Jollivet, D., and Cunningham, C. W. (2017). Gene flow between Atlantic and Pacific Ocean basins in three lineages of deep-sea clams (Bivalvia: Vesicomyidae: Pliocardiinae) and subsequent limited gene flow within the Atlantic. Deep Sea Res. II 137, 307-317. doi: 10.1016/j.dsr2.2016. 08.013

Landers, S. C., Sørensen, M. V., Beaton, K. R., Jones, C. M., Miller, J. M., and Stewart, P. M. (2018). Kinorhynch assemblages in the Gulf of Mexico continental shelf collected during a two-year survey. J. Exp. Mar. Biol. Ecol. 02, 81-90. doi: 10.1016/j.jembe.2017.05.013

Landers, S. C., Basshman, R. D., Miller, J. A., Ingels, J., Sánchez, N., and Sørensen, M. V. (2020). Kinorhynch communities from Alabama coastal waters. Mar. Biol. Res. 16, 494-504. doi: 10.1080/17451000.2020.1789660

Leduc, D., Rowden, A. A., Glud, R. N., Wenzhöfer, F., Kitazato, H., and Clark, M. R. (2016). Comparison between infaunal communities of the deep floor and edge 
of the Tonga Trench: possible effect of differences in organic matter supply. Deep Sea Res. I 116, 264-275. doi: 10.1016/j.dsr.2015.11.003

Lemenkova, P. (2019). Geomorphological modelling and mapping of the PeruChile Trench by GMT. Polish Cartographic Rev. 51, 181-194. doi: 10.2478/pcr2019-0015

Neuhaus, B., and Blasche, T. (2006). Fissuroderes, a new genus of Kinorhyncha (Cyclorhagida) from the deep sea and continental shelf of New Zealand and from the continental shelf of Costa Rica. Zool. Anz. 245, 19-52. doi: 10.1016/j. jcz.2006.03.003

Neuhaus, B. (2013). "Kinorhyncha (=Echinodera)," in Handbook of Zoology. Gastrotricha, Cycloneuralia and Gnathifera, Vol 1, Nematomorpha, Priapulida, Kinorhyncha, Loricifera, ed. A. Schmidt-Rhaesa (Berlin: De Gruyter).

Neuhaus, B., and Sørensen, M. V. (2013). Populations of Campyloderes sp. (Kinorhyncha, Cyclorhagida): one global species with significant morphological variation? Zool. Anz. 252, 48-75. doi: 10.1016/j.jcz.2012.03.002

Pardos, F., Herranz, M., and Sánchez, N. (2016). Two sides of a coin: the phylum Kinorhyncha in Panama. II) Pacific Panama. Zool. Anz. 265, 26-47. doi: 10. 1016/j.jcz.2016.06.006

Pawlowski, J., Fahrni, J., Lecroq, B., Cornelius, N., Excoffier, L., Cedhagen, T., et al. (2007). Bipolar gene flow in deep-sea benthic foraminifera. Mol. Ecol. 16, 4089-4096. doi: 10.1111/j.1365-294x.2007.03465.x

Perrone, F. M., Dell'Anno, A., Danovaro, R., Della Croce, N., and Thurston, M. H. (2002). Population biology of Hirondellea sp. nov. (Amphipoda: Gammaridea: Lysianassoidea) from the Atacama Trench (south-east Pacific Ocean). J. Mar. Biol. Assoc. 82, 419-425. doi: 10.1017/s0025315402005672

Ptatscheck, C., and Traunspurger, W. (2020). The ability to get everywhere: dispersal modes of free-living aquatic nematodes. Hydrobiologia 847, 35193547. doi: 10.1007/s10750-020-04373-0

Rex, M. A., Etter, R. J., Morris, J. S., Crouse, J., McClain, C. R., Johnson, N. A., et al. (2006). Global bathymetric patterns of standing stock and body size in the deep-sea benthos. Mar. Ecol. Prog. Ser. 317, 1-8. doi: 10.3354/meps317001

Sabbatini, A., Morigi, C., Negri, A., and Gooday, A. J. (2002). Soft-shelled benthic foraminifera from a hadal site $(7800 \mathrm{~m}$ water depth) in the Atacama Trench (SE Pacific): preliminary observations. J. Micropalaeontol. 21, 131-135. doi: 10.1144/jm.21.2.131

Sánchez, N., Pardos, F., and Sørensen, M. V. (2014a). A new kinorhynch genus, Mixtophyes (Kinorhyncha: Homalorhagida), from the Guinea Basin deep-sea, with new data on the family Neocentrophyidae. Helgol. Mar. Res. 68, 221-239. doi: 10.1007/s10152-014-0383-6

Sánchez, N., Pardos, F., and Sørensen, M. V. (2014b). Deep-sea Kinorhyncha: two new species from the Guinea Basin, with evaluation of an unusual male feature. Org. Divers. Evol. 14, 349-361. doi: 10.1007/s13127-014-0182-6

Sánchez, N., Pardos, F., and Martínez Arbizu, P. (2019). Deep-sea Kinorhyncha diversity from the polymetallic nodule fields at the clarion-clipperton fracture zone (CCZ). Zool. Anz. 282, 88-105. doi: 10.1016/j.jcz.2019.05.007

Schmidt, C., and Martínez Arbizu, P. (2015). Unexpectedly higher metazoan meiofauna abundance in the Kuril-Kamchatka trench compared to the adjacent abyssal plains. Deep Sea Res. II: Top. Stud. Oceanogr. 111, 60-75. doi: 10.1016/ j.dsr2.2014.08.019

Schmidt, C., Sattarova, V. V., Katrynski, L., and Martìnez Arbizu, P. (2019). New insights from the deep: meiofauna in the Kuril-Kamchatka Trench and adjacent abyssal plain. Prog. Oceanogr. 173, 192-207. doi: 10.1016/j.pocean.2019.02.010

Sørensen, M. V. (2018). Redescription of Echinoderes levanderi Karling, 1954 (Kinorhyncha: Cyclorhagida) - a kinorhynch tolerant to very low salinities. Eur. J. Taxon. 436, 1-17.

Sørensen, M. V., Rho, H. S., Min, W.-G., Kim, D., and Chang, C. Y. (2012). An exploration of Echinoderes (Kinorhyncha: Cyclorhagida) in Korean and neighboring waters, with the description of four new species and a redescription of E. tchefouensis Lou, 1934. Zootaxa 3368, 161-196. doi: 10.11646/zootaxa. 3368.1 .8

Sørensen, M. V., Dal Zotto, M., Rho, H. S., Herranz, M., Sánchez, N., Pardos, F., et al. (2015). Phylogeny of Kinorhyncha based on morphology and two molecular loci. PLoS One 10:e0133440. doi: 10.1371/journal.pone.0133440

Sørensen, M. V., Rohal, M., and Thistle, D. (2018). Deep-sea Echinoderidae (Kinorhyncha: Cyclorhagida) from the Northwest Pacific. Eur. J. Taxon. 456, $1-75$.

Sørensen, M. V., Thistle, D., and Landers, S. C. (2019). North American Condyloderes (Kinorhyncha: Cyclorhagida: Kentrorhagata): female dimorphism suggests moulting among adult Condyloderes. Zool. Anz. 282, 232-251. doi: 10.1016/j.jcz.2019.05.015
Sørensen, M. V., Goetz, F. E., Herranz, M., Chang, C. Y., Chatterjee, T., Durucan, F., et al. (2020). Description, redescription and revision of sixteen putatively closely related species of Echinoderes (Kinorhyncha: Cyclorhagida), with the proposition of a new species group - the Echinoderes dujardinii group. Eur. J. Taxon. 730, 1-101. doi: 10.5479/si.00810282.248

Steward, H. A., and Jamieson, A. J. (2018). Habitat heterogeneity of hadal trenches: considerations and implications for future studies. Prog. Oceanogr. 161, 47-65. doi: 10.1016/j.pocean.2018.01.007

Thormar, J., and Sørensen, M. V. (2010). Two new species of Echinoderes (Kinorhyncha: Cyclorhagida) from the Solomon Islands. Meiofauna Mar. 594, 67-96.

Turnewitsch, R., Falahat, S., Stehlikova, J., Oguri, K., Glud, R. N., Middleboe, M., et al. (2014). Recent sediment dynamics in hadal trenches: evidence for the influence of higher-frequency (tidal, near-inertial) fluid dynamics. Deep Sea Res. I 90, 125-138. doi: 10.1016/j.dsr.2014.05.005

Vincx, M. (1996). "Meiofauna in marine and fresh water sediments," in Methods for the Examination of Organismal Diversity in Soils and Sediments, ed. G. S. Hall (Cambridge: CAB International, University Press), 214-248.

von Huene, R., and Scholl, D. W. (1991). Observations at convergent margins concerning sediment subduction, subduction erosion, and the growth of continental crust. Rev. Geophys. 29, 279-316. doi: 10.1029/91rg00969

Wei, C.-L., Rowe, G. T., Escobar-Briones, E., Boetius, A., Soltwedel, T., Caley, M. J., et al. (2010). Global patterns and predictions of seafloor biomass using random forests. PLoS one 5:e15323. doi: 10.1371/journal.pone.0015323

Wenzhöfer, F., Oguri, K., Middelboe, M., Turnewitsch, R., Toyofuku, T., Kitazato, H., et al. (2016). Benthic carbon mineralization in hadal trenches: assessment by in situ O2 microprofile measurements. Deep Sea Res. I 116, 276-286. doi: 10.1016/j.dsr.2016.08.013

Wolff, T. (1960). The hadal community, an introduction. Deep Sea Res. 6, 95-124. doi: 10.1016/0146-6313(59)90063-2

Yamasaki, H., Kajihara, H., and Mawatari, S. F. (2012). First report of kinorhynchs from Hokkaido, Japan, including a new species of Pycnophyes (Pycnophyidae: Homalorhagida). Zootaxa 3425, 23-41. doi: 10.11646/zootaxa.3425.1.2

Yamasaki, H., Grzelak, K., Sørensen, M. V., Neuhaus, B., and George, K. H. (2018a). Echinoderes pterus sp. n. showing a geographically and bathymetrically wide distribution pattern on seamounts and on the deepsea floor in the Arctic ocean, Atlantic ocean, and the Mediterranean sea (Kinorhyncha, Cyclorhagida). ZooKeys 771, 15-40. doi: 10.3897/zookeys.771. 25534

Yamasaki, H., Neuhaus, B., and George, K. H. (2018b). Three new species of Echinoderidae (Kinorhyncha: Cyclorhagida) from two seamounts and the adjacent deep-sea floor in the Northeast Atlantic Ocean. Cah. Biol. Mar. 59, 79-106.

Yamasaki, H., Neuhaus, B., and George, K. H. (2019). Echinoderid mud dragons (Cyclorhagida: Kinorhyncha) from senghor seamount (NE Atlantic Ocean) including general discussion of faunistic characters and distribution patterns of seamount kinorhynchs. Zool. Anz. 282, 64-87. doi: 10.1016/j.jcz.2019.05.018

Yamasaki, H., Herranz, M., and Sørensen, M. V. (2020). An interactive key to species of Echinoderidae (Kinorhyncha). Zool. Anz. 287, 14-16. doi: 10.1016/j. jcz.2020.05.002

Zelinka, C. (1896). Demonstration der Tafeln der Echinoderes-monographie. Verh. Dtsch. Zool. Ges. 6, 197-199.

Zelinka, C. (1913). Der Echinoderen der Deutschen Südpolar-Expedition, 1901-1903. Band 14. Berlin: Walter de Gruyter.

Zeppilli, D., Leduc, D., Fontanier, C., Fontaneto, D., Fuchs, S., Gooday, A. J., et al. (2018). Characteristics of meiofauna in extreme marine ecosystems: a review. Mar. Biodivers. 48, 35-71. doi: 10.1007/s12526-0170815-z

Conflict of Interest: The authors declare that the research was conducted in the absence of any commercial or financial relationships that could be construed as a potential conflict of interest.

Copyright $\odot 2021$ Grzelak, Zeppilli, Shimabukuro and Sørensen. This is an openaccess article distributed under the terms of the Creative Commons Attribution License (CC BY). The use, distribution or reproduction in other forums is permitted, provided the original author(s) and the copyright owner(s) are credited and that the original publication in this journal is cited, in accordance with accepted academic practice. No use, distribution or reproduction is permitted which does not comply with these terms. 